\title{
OBSERVATIONS ON THE GENUS PINNULARIA SECTION DISTANTES (BACILLARIOPHYTA) FROM MACEDONIA; DIVERSITY AND DISTRIBUTION
}

\author{
Aleksandar Pavlov, Zlatko Levkov* \\ Institute of Biology, Faculty of Natural Sciences and Mathematics, Ss. Cyril and Methodius University, \\ Skopje, Republic of Macedonia \\ ${ }^{*}$ Corresponding author, e-mail: zlevkov@iunona.pmf.ukim.edu.mk
}

\begin{abstract}
Pinnularia is one of the largest and widely distributed freshwater diatom genera. Nevertheless, dedicated taxonomic studies to the section Distantes of Pinnularia are rather few. A notable diversity of Pinnularia taxa from the section Distantes has been observed from a variety of aquatic habitats on several mountain areas in Macedonia. In total, 12 taxa have been observed, of which three are described as new species: Pinnularia idsbensis, P. micevskii and $P$. subalpina. The main morphological features are given for all of the observed taxa. The distinctive features for the new species, in comparison with allied taxa, are also provided. Additional notes are given for the distribution and habitats where every taxon was observed. The habitats vary in type and altitude including high mountain lakes of glacial and non-glacial origin, springs, streams, rivers, rivulets and peat bogs, as well as aerated old drinking water wells and permanent or temporary wet rocks.
\end{abstract}

Key words: diatoms; Pinnularia; section Distantes; diversity; Macedonia

\section{INTRODUCTION}

The section Distantes (Cleve) Patrick in Patrick \& Reimer [1] of the genus Pinnularia Ehrenberg [2] was introduced by Cleve [3] as a group of taxa sharing linear-lanceolate to elliptical valves with distinctly broad and distantly spaced striae, as distinguishing features from the remaining Pinnularia taxa. Nevertheless, a valid taxonomic rank was given to this group with the description of the section Distantes within the genus Pinnularia by Patrick in Patrick \& Reimer [1].

The diversity of taxa belonging to the genus Pinnularia was emphasized as early as the end of the $19^{\text {th }}$ century by Cleve [3] and also on several occasions afterwards (Mayer [4], Hustedt in A. Schmidt et al. [5], Patrick \& Reimer [1]). More recent revisions of diatom floras from different geographical regions such as Europe (Krammer [6, 7]), South America (Metzeltin \& Lange-Bertalot [8, 9]), Asia (Metzeltin et al. [10]), and the Antarctic and Subantarctic (Van de Vijver et al. [11], Van de Vijver [12], Van de Vijver \& Zidarova [13], Van de Vijver et al. [14]) confirmed the notable diversity and wide distribution of Pinnularia taxa.

The section Distantes of Pinnularia has seldom been a focus of a thorough treatment, with the contributions of Mayer [4], Bock [15], Krammer [7] and Van de Vijver \& Zidarova [13] being the most comprehensive to date. Mayer [3] focused on many forms around P. borealis Ehrenberg [2] and P. lata (Brébisson) Rabenhorst [16], while Bock [15] compiled a complete set of the iconotype drawings known at that time of the taxa from this group. In his treatise of the European Pinnularia taxa Krammer [7] introduced ten new taxa in the section Distantes, three species and seven varieties. Most of his infraspecific additions are in $P$. borealis (four), two in P. rabenhorstii (Grunow) Krammer [7] and one in P. dubitabilis Hustedt [17]. A noteworthy diversity of the section Distantes has also been demonstrated for the Antarctic and Subantarctic region. Two infraspecific taxa in $P$. rabenhorstii and one species have been introduced by Van de Vijver et al. [11] from Ile de la Possession. Later on, Van de Vijver [12] described two species from King George 
Island, Van de Vijver \& Zidarova [13] contributed five taxa, four species and one variety in $P$. borealis, from Livingston Island, and Van de Vijver in Van de Vijver et al. [14] made an addition of one species from Ile Amsterdam.

Recently, Souffreau et al. [18] applied the principles of molecular phylogenetics and presented evidence on a distinct Antarctic lineage of $P$. borealis. An assessment of the molecular divergence revealed $P$. borealis as the oldest known diatom species complex, and the Antarctic lineage of this taxon is estimated to have diverged after the geographical and thermal isolation of the Antarctic continent. In addition, the temperature-dependent growth characteristics (lower optimal growth temperature and upper lethal temperature) indicate a niche differentiation in the Antarctic lineage of $P$. borealis (Souffreau et al. [18]).

An appealing diversity of taxa from the section Distantes of Pinnularia has been observed on different mountains in Macedonia (Levkov et al. [19]). Nevertheless, the diversity of taxa from this group was not restricted to mountain areas only, but also observed in the lowland regions in Macedonia (Petrovska \& Stojanov [20, 21], Krstic \& Stojanovski [22]). The aquatic habitats of importance for these taxa vary in type and altitude and include high mountain lakes of glacial and non glacial origin, mountain springs, streams, rivers and rivulets, and also peat bogs. In addition, somewhat extreme habitats as wet rocks, of permanent or temporal moisture, and old wells used as a drinking water source have also been found as an appropriate environment for these taxa (Krammer [7]). Hence, this study is an attempt for a proper documentation of the diversity of Pinnularia taxa from the section Distantes in Macedonia. Still, we would refrain from pointing to this observation as a final one. Many additional taxa, observed with a single or a few specimens only, need correct identification and therefore we believe that this systematic group is even more diverse in the area studied.

\section{EXPERIMENTAL SECTION}

The samples examined were collected on various sampling campaigns from 1995 to 2012. The mountains where samples were collected are: Šar Planina in the western part of Macedonia, Jablanica and Pelister in the south-western part, Kožuf and Nidže in the southern part, and Osogovo in the eastern part of Macedonia. In addition, samples were collected from Mountain Bistra and the region of Mariovo in the central part of Macedonia. The altitude range of the sampling sites varies between 200 and $2500 \mathrm{~m}$ a.s.l.

The aquatic habitats sampled include highaltitude lakes of glacial and non-glacial origin, springs, streams, rivers and rivulets, ponds and pools of various size and also peat bogs. Furthermore, aerated habitats such as wet walls and rock pools of permanent or temporary aqueous periods, and even old drinking water wells have been sampled. The substrate sampled was of organic sediment, sand, rock scrape, submerged plants, macrophyte algae and a variety of moss species of different moisture.

The organic content was removed from the samples by acid digestion, with the addition of $2 \mathrm{ml}$ of $\mathrm{K}_{2} \mathrm{MnO}_{4}$ and $4 \mathrm{ml}$ of $\mathrm{HCl}$ to a small (ca $2 \mathrm{ml}$ ) subsample. Permanent microscope slides were mounted in Naphrax ${ }^{\circledR}$. Slide observations were performed with a Nikon E-80i light microscope, and photomicrographs were made with a Nikon Coolpix 600 digital camera. Photomicrographs were made to show most of the size diminution of each taxon. The sequence of the taxa in the plates is based on morphological similarity among the taxa, exceptions made only for better utilisation of the available space. The observations on the taxa in the text follow the sequence of the taxa in the plates. The proper identification of these taxa was based on the works of Mayer [4], Bock [15], Krammer [7], Van de Vijver [12], Van de Vijver et al. [11, 14] and Van de Vijver \& Zidarova [13], whereas the terminology used for the descriptions of the taxa mainly follows Krammer [7], Patrick \& Reimer [1], Van de Vijver et al. [11] and Van de Vijver \& Zidarova [13]. An identification key is provided at the end as assistance in the identification of the taxa.

All samples and microscope slides are housed at the Macedonian National Diatom Collection (MKNDC) at the Institute of Biology in Skopje, Macedonia. The type slides are also housed at the MKNDC and isotype slides are deposited at the Friedrich Hustedt Diatom Study Centre (BRM).

\section{RESULTS AND DISCUSSION}

In total, 12 taxa have been observed, four species and eight named varieties (Table 1). Of these, three species are described as new: Рinnularia idsbensis, P. micevskii and P. subalpina. 
Table 1. An overview of the main morphological features of the Pinnularia taxa, section Distantes, observed in Macedonia

\begin{tabular}{|c|c|c|c|c|c|}
\hline Taxon & $\begin{array}{l}\text { Valve outline/ } \\
\text { Valve margins }\end{array}$ & Valve apices & Central area & $\begin{array}{l}\text { Length/Width } \\
(\mu \mathrm{m})\end{array}$ & $\begin{array}{l}\text { Striae } \\
\text { (in } 10 \mu \mathrm{m} \text { ) }\end{array}$ \\
\hline $\begin{array}{l}\text { P. borealis var. } \\
\text { borealis }\end{array}$ & $\begin{array}{l}\text { Linear-elliptic/ } \\
\text { weakly convex }\end{array}$ & Unprotracted, rounded & $\begin{array}{l}\text { Rhombic-lanceolate } \\
\text { to rectangular }\end{array}$ & $\begin{array}{l}23.5-43.0 / \\
7.5-10.5\end{array}$ & $4-6$ \\
\hline $\begin{array}{l}\text { P. borealis var. } \\
\text { islandica }\end{array}$ & $\begin{array}{l}\text { Linear-elliptic/ } \\
\text { weakly convex }\end{array}$ & $\begin{array}{l}\text { Unprotracted, broadly } \\
\text { rounded }\end{array}$ & $\begin{array}{l}\text { Rhombic-lanceolate } \\
\text { to lanceolate }\end{array}$ & $\begin{array}{l}25.0-47.5 / \\
9.5-13.0\end{array}$ & $4-6$ \\
\hline $\begin{array}{l}\text { P. borealis var. } \\
\text { scalaris }\end{array}$ & $\begin{array}{l}\text { Linear to linear- } \\
\text { lanceolate/parallel }\end{array}$ & $\begin{array}{l}\text { Weakly protracted, } \\
\text { rounded }\end{array}$ & $\begin{array}{l}\text { Rhombic-lanceolate } \\
\text { to rectangular }\end{array}$ & $\begin{array}{l}34.5-51.0 / \\
8.0-10.0\end{array}$ & $4-7$ \\
\hline $\begin{array}{l}\text { P. borealis var. } \\
\text { subislandica }\end{array}$ & $\begin{array}{l}\text { Linear-lanceolate/ } \\
\text { weakly convex }\end{array}$ & $\begin{array}{l}\text { Not or weakly } \\
\text { protracted, truncate }\end{array}$ & $\begin{array}{l}\text { Rhombic-lanceolate } \\
\text { to rounded }\end{array}$ & $\begin{array}{l}22.5-42.5 / \\
7.0-9.0\end{array}$ & $4-6$ \\
\hline $\begin{array}{l}\text { P. dubitabilis } \\
\text { var. dubitabilis }\end{array}$ & $\begin{array}{l}\text { Rectangular, linear/ } \\
\text { Parallel }\end{array}$ & $\begin{array}{l}\text { Unprotracted, rounded } \\
\text { to truncate }\end{array}$ & Absent & $\begin{array}{l}28.0-40.0 / \\
7.0-8.5\end{array}$ & $4-5$ \\
\hline P. idsbensis & $\begin{array}{l}\text { Linear/consistently } \\
\text { parallel }\end{array}$ & $\begin{array}{l}\text { Unprotracted, broadly } \\
\text { rounded }\end{array}$ & Rhombic-lanceolate & $\begin{array}{l}33.0-71.5 / \\
11.0-14.0\end{array}$ & $4-6$ \\
\hline P. lata var. lata & Linear-elliptic/convex & $\begin{array}{l}\text { Unprotracted, broadly } \\
\text { rounded }\end{array}$ & $\begin{array}{l}\text { Asymmetrical, } \\
\text { lanceolate }\end{array}$ & $\begin{array}{l}128.5-148.0 / \\
36.0-39.5\end{array}$ & $2-3$ \\
\hline $\begin{array}{l}\text { P. lata } \\
\quad \text { var. minor }\end{array}$ & $\begin{array}{l}\text { Linear-elliptic/slightly } \\
\text { convex }\end{array}$ & $\begin{array}{l}\text { Unprotracted/narrowly } \\
\text { rounded }\end{array}$ & $\begin{array}{l}\text { Rhombic-lanceolate, } \\
\text { rarely rectangular }\end{array}$ & $\begin{array}{l}36.0-47.0 / \\
12.5-14.0\end{array}$ & $5-7$ \\
\hline P. micevskii & Linear/parallel & $\begin{array}{l}\text { Unprotracted, } \\
\text { subrostrate }\end{array}$ & $\begin{array}{l}\text { Asymmetrical, } \\
\text { rhombic-lanceolate }\end{array}$ & $\begin{array}{l}81.0-112.0 / \\
22.0-26.0\end{array}$ & $3-4$ \\
\hline $\begin{array}{l}\text { P. rabenhorstii } \\
\text { var. franconica }\end{array}$ & $\begin{array}{l}\text { Linear/consistently } \\
\text { parallel }\end{array}$ & Protracted, subrostrate & $\begin{array}{l}\text { Rhombic-lanceolate } \\
\text { to rounded }\end{array}$ & $\begin{array}{l}43.5-61.0 / \\
11.0-14.0\end{array}$ & $4-7$ \\
\hline $\begin{array}{l}\text { P. rabenhorstii } \\
\text { var. rabenhorstii }\end{array}$ & $\begin{array}{l}\text { Linear-lanceolate/ } \\
\text { weakly convex }\end{array}$ & $\begin{array}{l}\text { Unprotracted, broadly } \\
\text { truncate }\end{array}$ & $\begin{array}{l}\text { Rhombic-lanceolate } \\
\text { to lanceolate or } \\
\text { rounded }\end{array}$ & $\begin{array}{l}44.0-72.5 / \\
13.0-17.0\end{array}$ & $4-5$ \\
\hline P. subalpina & $\begin{array}{l}\text { Linear-elliptic to } \\
\text { elliptic/parallel to } \\
\text { strongly convex }\end{array}$ & $\begin{array}{l}\text { Unprotracted, broadly } \\
\text { rounded }\end{array}$ & $\begin{array}{l}\text { Asymmetrical, } \\
\text { rhombic-lanceolate }\end{array}$ & $\begin{array}{l}52.0-84.0 / \\
20.0-21.5\end{array}$ & $3-5$ \\
\hline
\end{tabular}

\section{Pinnularia micevskii Levkov, Pavlov \& Nakov sp. nov. (Figs 1: 1-3; 2: 1-4)}

Description: Valves broadly linear, with parallel margins and unprotracted, broadly rounded, subrostrate apices. Valve length $81.0-112.0 \mu \mathrm{m}$, and valve width $22.0-26.0 \mu \mathrm{m}(\mathrm{n}=15)$. Axial area broad, $1 / 5$ to $1 / 6$ of valve width, linear, expanded near central area. Central area asymmetrical, large rhombic lanceolate, $1 / 2$ of valve width. Central area well defined, bordered on each side by $2-4$ shortened striae. Irregular silica ornamentation present in central and axial areas, in some specimens also observable within interstriae. Raphe weakly to moderately lateral, outer raphe fissures slightly curved and inner fissures nearly linear. Proximal raphe endings deflected towards one valve side, terminated with large and distinct, tear-drop shaped central pores. Distal raphe fissures sickle-shaped, positioned in distinct terminal areas, clearly discernible in LM. Transapical striae broad, closely spaced, radiate in mid-valve and parallel near valve apices, 3-4 in $10 \mu \mathrm{m}$. Interstriae of equal or narrower width than striae.
Type (here designated): Mountain of Šar Planina, Lake Crno, sediment, depth $0.5 \mathrm{~m}$, collection date: 7 August 2003, leg. Z. Levkov (Accession no. MKNDC 003048). Holotype! illustrated in Fig. 1: 1 (circled specimen on slide MKNDC 003048/A). Slide BRM Zu9/47 (isotype!).

Etymology: The specific epithet is given to honour late Acad. Kiril Micevski, from the Institute of Biology in Skopje, for his pioneering efforts and remarkable contribution to plant taxonomy in Macedonia.

Distribution: Pinnularia micevskii has been observed on Mt. Šar Planina, in the type locality, within the epipelon from glacial Lake Crno, at an altitude of $2165 \mathrm{~m}$ a.s.l. This species was also observed on Mt. Jablanica, as an epiphyte on mosses from a peat bog above glacial Lake Podgorechko, at an altitude of $1950 \mathrm{~m}$ a.s.l. Pinnularia micevskii was fairly abundant in both samples.

Observations: Pinnularia micevskii is most similar to $P$. rabenhorstii var. rabenhorstii (Grunow) Krammer [7] in respect to the valve outline, the shape of the valve apices and the central area. A 
distinction between the two taxa can be made due to the valve width, with $P$. rabenhorstii var. rabenhorstii being consistently narrower $(16.0-18.0 \mu \mathrm{m})$. Other infraspecific taxa within $P$. rabenhorstii $(P$. rabenhorstii var. franconica Krammer [7], $P$. rabenhorstii var. cuneata Krammer \& Lange-Bertalot in Krammer [7], P. rabenhorstii var. elegans (Hustedt) Krammer [7]) have considerable smaller valve size. Furthermore, $P$. rabenhorstii var. cuneata and $P$. rabenhorstii var. elegans have cuneate and narrower rounded valve ends. Pinnularia subrabenhorstii Krammer [7] has smaller valve size and weakly undulated valve margins, thus making the distinction from $P$. micevskii straightforward.

A large-celled Pinnularia species, which belongs to the section Distantes, that is similar in valve size to $P$. micevskii, is $P$. obaesa Van de Vijver [12], described from the Antarctic King George Island. Nevertheless, the valves of $P$. obaesa have a rectangular outline with very broadly rounded apices which are rarely subrostrate. In comparison, the valve outline in $P$. micevskii is not rectangular and the valve ends are consistently subrostrate with the valve margins strongly tapering towards the apices. Another taxon, P. australorabenhorstii Van de Vijver [12], was also added to the section Distantes from the Antarctic King George Island (Van de Vijver [12]). However, $P$. australorabenhorstii can be distinguished from $P$. micevskii by the valve outline (linear-elliptical to lanceolate-elliptical with convex valve margins in $P$. australorabenhorstii), valve size (length $=50.0-65.0$ $\mu \mathrm{m}$, width $=16.0-17.5 \mu \mathrm{m}$ in $P$. australorabenhorstii) and stria density $(6-7(8) / 10 \mu \mathrm{m}$ in $P$. australorabenhorstii).

Pinnularia micevskii does resemble $P$. kerguelensis Heiden (in Heiden \& Kolbe [23]) with regard to the valve outline and size, as well as the shape of the valve apices. The proposed lectotype for P. kerguelensis by Simonsen [24] is only a fragment of a valve that does not really allow proper identification. A decent photographic documentation for $P$. kerguelensis is provided by Van de Vijver et al. [11]. A distinction from P. micevskii can be observed in the linear-lanceolate to linearelliptic valves, with slightly convex valve margins in $P$. kerguelensis. Furthermore, irregular silica ornamentation is present in the axial and central areas of $P$. micevskii, a feature absent in $P$. kerguelensis.

We consider the combination of characters (valve outline, shape of the valve apices, valve size, irregular silica ornamentation) in $P$. micevskii as sufficient for a straightforward distinction from other taxa of the section Distantes in Pinnularia.

\section{Pinnularia lata (Brébisson) Rabenhorst var. lata [16] (Figs 3: 1-3)}

Basionym: Frustulia lata Brébisson [25].

Valves broadly linear-elliptic, with convex margins and broadly rounded, unprotracted apices. Valve length $128.5-148.0 \mu \mathrm{m}$, and valve width $36.0-39.5 \mu \mathrm{m}(\mathrm{n}=15)$. Axial area broad, $1 / 4$ to $1 / 5$ of valve width, linear to lanceolate, gradually expanding towards central area. Central area asymmetrical, large lanceolate, $1 / 2$ to $1 / 3$ of valve width. Central area well defined, bordered on each side by 4-5 shortened striae. Raphe strongly lateral, outer raphe fissures weakly curved to linear, and inner fissures weakly curved. Proximal raphe endings strongly deflected towards one valve side, terminated with large and distinct, comma shaped central pores. Distal raphe fissures sickle shaped, positioned in prominent terminal areas, clearly discernible in LM. Transapical striae broad, widely separated, radiate in mid-valve becoming parallel near valve apices, $2-3$ in $10 \mu \mathrm{m}$. Interstriae prominent, of equal or greater width than striae.

Distribution: Pinnularia lata var. lata was observed only from the epipelon of glacial Lake Crno, on Mt. Šar Planina. Lake Crno is one of the largest glacial lakes in Macedonia, with surface area of $33520 \mathrm{~m}^{2}$ and mean depth of $5 \mathrm{~m}$. Lake Crno is located at an altitude of $2165 \mathrm{~m}$ a.s.l. Krammer [7] notes $P$. lata var. lata as widespread in the northern alpine regions of Europe, in oligotrophic waters rich in oxygen and also in aerial habitats.

Observations: The morphology of $P$. lata var. lata, observed herein from Lake Crno, resembles the lectotype specimens depicted in Krammer [7]. This species might be confused with $P$. micevskii, but a distinction can be made due to the consistently convex valve margins in $P$. lata var. lata (opposed to the consistently parallel margins in P. micevskii) and the absence of the irregular silica ornamentation in the axial and central areas of $P$. lata var. lata (feature clearly observable in $P$. micevskii). Furthermore, $P$. micevskii has much narrower valves $(\mathrm{W}=22.0$ $26.0 \mu \mathrm{m})$ compared to P. lata var. lata.

\section{Pinnularia lata var. minor (Grunow) Cleve [3]} (Figs 4: 1-10) [26].

\section{Basionym: Navicula lata var. minor Grunow}

Valves linear-elliptic, with slightly convex margins and unprotracted, narrowly rounded apices. Valve length $36.0-47.0 \mu \mathrm{m}$, and valve width $12.5-$ $14.0 \mu \mathrm{m}(\mathrm{n}=35)$. Axial area narrow to moderately wide, $1 / 6$ to $1 / 8$ of valve width, linear, expanded 
near central area. Central area large rhombiclanceolate, rarely rectangular, $1 / 2$ of valve width or wider. Central area well defined, bordered on each side by $2-4$ shortened striae. Raphe weakly lateral, outer raphe fissures linear to weakly curved, and inner fissures linear. Proximal raphe endings deflected towards one valve side, terminated with large and distinct, tear-drop shaped central pores. Distal raphe fissures sickle-shaped, positioned in prominent terminal areas, clearly discernible in LM. Distal raphe fissures occasionally question mark shaped. Transapical striae broad, closely spaced, radiate in mid-valve becoming parallel to weakly convergent near valve apices, 5-7 in $10 \mu \mathrm{m}$. Interstriae of narrower width than striae.

Distribution: Pinnularia lata var. minor was found only on Mt. Šar Planina, western Macedonia. It was observed within the epipelon of the spring of River Pena, at an altitude of ca. $2500 \mathrm{~m}$ a.s.l. At lower altitude it was observed in a mixed sample of organic sediment and green algal filaments from a small lake near Čardak, at 2320 m a.s.l.

Observations: The line drawing for $N$. lata var. minor in Grunow [26] is $45.0 \mu \mathrm{m}$ long and $13.0 \mu \mathrm{m}$ wide, with $4-5$ striae in $10 \mu \mathrm{m}$. No distinctive features were observed between the specimens from Macedonia and the protologue drawing for $P$. lata var. minor. In addition, one specimen of $P$. lata var. minor is depicted in Reichardt [27], from Grazer Bergland in Austria, being somewhat larger than the specimens observed herein (length $=59.0 \mu \mathrm{m}$, width $=15.0 \mu \mathrm{m}$, striae $=5$ in $10 \mu \mathrm{m})$.

\section{Pinnularia subalpina sp. nov. (Figs 5: 1-7)}

Description: Valves linear-elliptic in large and medium-sized specimens (with parallel to weakly convex margins) to elliptic in smaller specimens (with strongly convex margins). Valve apices broadly rounded, unprotracted, subrostrate only in largest specimens. Valve length 52.0-84.0 $\mu \mathrm{m}$, and valve width $20.0-21.5 \mu \mathrm{m}(\mathrm{n}=20)$. Axial area broad, rarely narrow, $1 / 5$ to $1 / 6$ of valve width, linear, expanded near central area. Axial area lanceolate in smallest specimens only. Central area asymmetrical, large rhombic-lanceolate, 1/2 of valve width. Central area mostly well defined, bordered on each side by 2-4 shortened striae. Raphe strongly lateral, outer raphe fissures weakly curved to linear, and inner fissures linear. Proximal raphe endings deflected towards one valve side, terminated with large and distinct, tear-drop shaped central pores. Distal raphe fissures sickle-shaped, positioned in prominent terminal areas, clearly discernible in LM. Transapical striae broad, closely spaced, radiate in mid-valve and parallel near valve apices, $3-5$ in $10 \mu \mathrm{m}$. Interstriae of equal or narrower width than striae. Only in the smallest specimens the interstriae are more prominent.

Type (here designated): Mt. Šar Planina, Lake Crno, sediment, depth $0.5 \mathrm{~m}$, collection date: 7 August 2003, leg. Z. Levkov (Accession no. MKNDC 003047). Holotype! Illustrated in Figure 5: 3 (circled specimen on slide MKNDC 003047/A). Slide BRM Zu9/49 (isotype!).

Etymology: The specific epithet ("subalpina") refers to its resemblance with $P$. alpina, but nevertheless smaller valve size.

Distribution: Pinnularia subalpina was observed from two lakes on Mt. Šar Planina, Lake Crno located at an altitude of $2165 \mathrm{~m}$ a.s.l. and a small lake near Čardak, located at an altitude of ca. $2300 \mathrm{~m}$ a.s.1. In Lake Crno this species was observed within the epipelon of the lake's sediment at depth of about $0.5 \mathrm{~m}$, whereas in the small lake near Čardak it was observed from a mixed sample of organic sediment and green algal filaments.

Observations: Pinnularia subalpina is most similar to P. alpina W. Smith [28] in respect to the valve outline, the shape of the valve apices and the central pores. Nevertheless, the valve size of $P$. alpina (length $=100.0-220.0 \mu \mathrm{m}$, width $=38.0$ $48.0 \mu \mathrm{m}$, given in Krammer [7]) is significantly larger than in $P$. subalpina. Furthermore, the axial area in $P$. alpina is distinctly lanceolate in comparison to the mostly linear axial area in $P$. subalpina.

With respect to the valve outline $P$. subalpina also resembles $P$. lata var. curta (Grunow) Cleve [3] (=Navicula lata var. curta Grunow [29]). The drawing of N. lata var. curta by Grunow [29] is wider (width $=29.5 \mu \mathrm{m}$ ) than any of the observed specimens of $P$. subalpina. Hence, we find the valve width as a sufficient feature to tell apart $P$. subalpina from $P$. lata var. curta. A similarity between P. lata var. curta f. elliptica Mayer [4] and $P$. subalpina can be observed with respect to the valve size and the shape of the central area. Pinnularia lata var. curta f. elliptica can be distinguished from $P$. subalpina due to the more rhombic valve outline and narrower rounded valve apices.

Pinnularia subalpina is similar to P. lata in respect to the valve outline, the shape of the central area and the shape of the central pores. Nevertheless, valves of $P$. lata are significantly larger (length $=128-148 \mu \mathrm{m}$, width $=36.0-39.5 \mu \mathrm{m}$, observed herein). Values for the lowest valve length $(50.0 \mu \mathrm{m})$ and the lowest valve width $(14.0$ 
$\mu \mathrm{m})$ of $P$. lata given in Krammer [7] might not be accurate, since all of his depicted specimens are longer that $88.0 \mu \mathrm{m}$ and wider than $28.0 \mu \mathrm{m}$. Pinnularia subalpina can be distinguished from $P$. lata due to the valve size.

Pinnularia subalpina is comparable to $P$. rabenhorstii var. rabenhorstii (Grunow) Krammer [7] (=Navicula rabenhorstii Grunow [30]) with regard to the valve length, the shape of the central area and the stria density. Pinnularia subalpina can be distinguished from $P$. rabenhorstii var. rabenhorstii due to the narrower valve width (16.0-18.0 $\mu \mathrm{m})$, consistently linear valves and broadly subrostrate valve apices in $P$. rabenhorstii var. rabenhorstii.

Pinnularia alpiniformis Van de Vijver \& Beyens in Van de Vijver et al. [11] is characterized by a very broad axial area with lanceolate shape and a large, asymmetrical central area which is not clearly separated from the axial area. It can be easily differentiated from $P$. subalpina by the shape of the axial and central areas and the valve width.

\section{Pinnularia rabenhorstii (Grunow) Krammer var. rabenhorstii [7] (Figs 6: 1-10)}

Basionym: Navicula rabenhorstii Grunow [30].

Valves linear-lanceolate, with weakly convex margins and unprotracted, broadly truncate apices. Valve length 44.0-72.5 $\mu \mathrm{m}$, and valve width 13.0$17.0 \mu \mathrm{m}(\mathrm{n}=30)$. Axial area broad, $1 / 5$ to $1 / 6$ of valve width, linear, expanded near central area. Central area asymmetrical, large rhombic-lanceolate to lanceolate, rarely rounded, $1 / 2$ of valve width. Central area well defined, bordered on each side by 2-3 shortened striae. Raphe weakly lateral, strongly lateral only in longest specimens, outer raphe fissures linear, rarely weakly curved, and inner fissures linear. Proximal raphe endings deflected towards one valve side, terminated with large and distinct, tear-drop shaped central pores. Distal raphe fissures sickle-shaped, positioned in prominent terminal areas, clearly discernible in LM. Transapical striae broad, mostly closely spaced, radiate in mid-valve becoming parallel to weakly convergent near valve apices, 4-5 in $10 \mu \mathrm{m}$. Interstriae of equal or narrower width than striae, rarely wider.

Distribution: Pinnularia rabenhorstii var. rabenhorstii was observed on several localities on Mt. Sar Planina. It was found within the epipelon of the sediment from Lake Crno (2165 m a.s.l.), at $0.5 \mathrm{~m}$ of depth, and as an epiphyte on the macrophyte vegetation from a stream above Lake Crno, at an altitude of ca. $2200 \mathrm{~m}$ a.s.l. It was also observed in a mixed sample of organic sediment and green algal filaments from a small lake near Cardak, also at altitude of ca. $2300 \mathrm{~m}$ a.s.l. Pinnularia rabenhorstii var. rabenhorstii was also found in the epipelon of the organic sediment from Karanikoličko Lake, at $0.2 \mathrm{~m}$ of depth. Karanikoličko Lake is one of the largest lakes on Mt. Šar Planina, with surface area of $26240 \mathrm{~m}^{2}, 5.6 \mathrm{~m}$ of water depth and is located at $2185 \mathrm{~m}$ a.s.l. In addition, $P$. rabenhorstii var. rabenhorstii was observed as an epiphyte on mosses from the temporary lake Bolnici I, near glacial Lake Golemo on Mountain of Pelister, at an altitude of $2225 \mathrm{~m}$ a.s.l.

Observations: Pinnularia rabenhorstii var. rabenhorstii was lectotypified by Krammer [7]. The specimens of $P$. rabenhorstii var. rabenhorstii observed in Macedonia show similar morphological features as the lectotype specimen from Thuringia, Germany (Figure 5: 4 in Krammer [7]). Small differences can be noticed in the shape of the valve apices. According to Krammer [7] the valve apices in $P$. rabenhorstii var. rabenhorstii are broadly subrostrate, while the population from Macedonia is characterized by broadly truncate apices. However, all other features (e.g. valve size and outline, stria density, shape and width of the axial and central area) are comparable to the type. Pinnularia australoborealis Van de Vijver \& Zidarova [13] has strictly lanceolate valves with convex margins and subrostrate apices, opposite to the almost linear valves, with unprotracted and broadly truncate apices in $P$. rabenhorstii var. rabenhorstii. Additionally, the valves of $P$. australoborealis are much narrower than in $P$. rabenhorstii var. rabenhorstii.

\section{Pinnularia rabenhorstii var. franconica Krammer [7] (Figs 7: 1-12)}

Valves linear, with consistently parallel margins. Valve apices protracted, broadly rounded, subrostrate. Valve length $43.5-61.0 \mu \mathrm{m}$, and valve width 11.0-14.0 $\mu \mathrm{m}(\mathrm{n}=30)$. Axial area narrow, $1 / 6$ to $1 / 8$ of valve width, linear, expanded near central area. Axial area rarely broad, 1/4 of valve width and lanceolate. Central area large rhombiclanceolate to rounded, rarely rectangular, 1/2 of valve width or wider. Central area mostly well defined, bordered on each side by 2-4 shortened striae. Raphe weakly lateral, outer raphe fissures linear to weakly curved, and inner fissures linear. Proximal raphe endings weakly deflected towards one valve side, terminated with large and distinct, tear-drop shaped central pores. Distal raphe fissures sickle-shaped, positioned in prominent terminal areas, clearly discernible in LM. Distal raphe 
fissures rarely question mark shaped. Transapical striae broad, closely spaced, radiate in mid-valve becoming parallel to weakly convergent near valve apices, 4-7 in $10 \mu \mathrm{m}$. Striae rarely distantly spaced. Interstriae of equal or narrower width than striae, rarely wider.

Distribution: Pinnularia rabenhorstii var. franconica was observed on Pelister and Šar Planina mountains and in the region of Mariovo. On Mt. Pelister this species was found as epiphytic on mosses from the temporary lake Bolnici I, near glacial Lake Golemo, at an altitude of $2225 \mathrm{~m}$ a.s.l. On Mt. Šar Planina P. rabenhorstii var. franconica was observed on several localities in various habitats, springs, streams and lakes. It was found within the epipelon from the spring of River Pena, at an altitude of ca. $2500 \mathrm{~m}$ a.s.l. It was also observed as an epiphyte on the macrophyte vegetation from a stream above glacial Lake Crno (ca. $2200 \mathrm{~m}$ a.s.l). Lake Crno is located at an altitude of $2165 \mathrm{~m}$ a.s.l. At somewhat higher altitude, this species was observed in a mixed sample of organic sediment and green algal filaments from a small lake near Cardak (ca. $2300 \mathrm{~m}$ a.s.l.). The lowest altitude on Mt. Šar Planina where this species was observed is 2185 m a.s.l. of Karanikoličko Lake, where it was found within the epipelon of the lake's sediment at $0.2 \mathrm{~m}$ of depth.

This species was additionally observed in the region of Mariovo, central Macedonia. In Mariovo, $P$. rabenhorstii var. franconica was found in an aerial habitat, as an epiphyte on the macrophyte vegetation of a temporary wet rock, before the vilage of Dunje.

Observations: Pinnularia rabenhorstii var. franconica was described from a rivulet near Reichenbach, Germany. Krammer [7] notes this taxon as distributed in oligotrophic waters, frequent within the epipelon. In Macedonia P. rabenhorstii var. franconica was most abundant as an epiphyte on the moss vegetation from a temporary lake near Lake Golemo on Mt. Pelister, south-western Macedonia.

\section{Pinnularia idsbensis sp. nov.}

(Figs 8: 1-12; 11: 14-19)

Description: Valves linear, with consistently parallel margins and unprotracted, broadly rounded apices. Valve length 33.0-71.5 $\mu \mathrm{m}$, and valve width $11.0-14.0 \mu \mathrm{m}(\mathrm{n}=35)$. Axial area narrow to moderately wide, $1 / 6$ to $1 / 8$ of valve width, linear, expanded near central area. Central area rhombiclanceolate, $1 / 2$ to $1 / 3$ of valve width or smaller. Central area rarely asymmetrical, mostly well defined, bordered on each side by 1-3 shortened striae. Raphe weakly lateral, outer raphe fissures linear to weakly curved and inner fissures linear. Proximal raphe endings deflected towards one valve side, terminated with large and distinct, teardrop shaped central pores. Distal raphe fissures sickle-shaped, positioned in prominent terminal areas, clearly discernible in LM. Distal raphe fissures rarely question mark shaped. Transapical striae broad, closely spaced, radiate in mid-valve becoming parallel to weakly convergent near valve apices, 4-6 in $10 \mu \mathrm{m}$. Interstriae of equal or narrower width than striae.

Type (here designated): Mountain of Pelister, temporary lake Bolnici I, mosses, collection date: 17 September 2006, leg. A. Pavlov (Accession no. MKNDC 002967). Holotype! Illustrated in Figure 8: 2 (circled specimen on slide MKNDC 002967/D). Slide BRM Zu9/48 (isotype!).

Etymology: The specific epithet ("idsbensis") refers to IDSB (Biology Students' Research Society) from Skopje, for the remarkable contribution of its members throughout the last 19 years in biodiversity research and conservation in Macedonia. Even more, a large number of samples in the Macedonian National Diatom Collection (MKNDC) have been collected during the annual sampling campaigns organized by the IDSB.

Distribution: Pinnularia idsbensis was observed on Pelister and Šar Planina mountains. It was more abundant on Mt. Pelister, as an epiphyte on mosses from the temporary lake Bolnici I, near glacial Lake Golemo. Lake Bolnici I is a cirquemoraine lake, located at an altitude of $2225 \mathrm{~m}$ a.s.l. The basin is filled with water during the period of intensive snow-melt from March till May, with a maximum depth of $0.4 \mathrm{~m}$ and average depth $0.3 \mathrm{~m}$. It is only fed by snow-melt and rainfall. Pinnularia idsbensis was also found within the epipelon of the same lake. On Mt. Šar Planina this species was also observed as epipelic from the spring of River Pena, located at an altitude of ca. $2500 \mathrm{~m}$ a.s.l.

Observations: Pinnularia idsbensis is most similar to $P$. laterotundata Van de Vijver \& Zidarova [13] in respect to the valve outline, valve size and stria density. The larger valves of $P$. idsbensis have less rounded ends, with the valve margins tapering towards the apices. Furthermore, the transapical striae of $P$. idsbensis are more radiate in mid-valve as compared to the weakly radiate striae of $P$. laterotundata.

Pinnularia laterotundata was described from Byers Peninsula, Livingston Island, Antarctica. Van de Vijver \& Zidarova [13] found it quite rare on 
Livingston Island with a note that it was also observed on James Ross Island.

\section{Pinnularia borealis Ehrenberg var. borealis [2]} (Figs 9: 1-25; 10: 17-25)

Valves linear-elliptic, with weakly convex, rarely parallel, margins and unprotracted rounded apices. Valve length 23.5-43.0 $\mu \mathrm{m}$, and valve width 7.5-10.5 $\mu \mathrm{m}(\mathrm{n}=65)$. Axial area moderately broad, $1 / 4$ to $1 / 7$ of valve width, linear and expanded near central area or lanceolate and gradually widening towards central area. Central area asymmetrical, rhombic-lanceolate to rectangular, 1/2 of valve width or wider. Central area vaguely defined, rarely well defined, bordered on each side by 1-3 shortened striae. Raphe weakly lateral, outer raphe fissures linear to weakly curved, and inner fissures linear. Proximal raphe endings deflected towards one valve side, terminated with distinct, round to tear-drop shaped central pores. Distal raphe fissures sickle-shaped, positioned in small terminal areas, clearly discernible in LM. Transapical striae broad, distantly spaced, radiate in mid-valve becoming parallel to weakly convergent near valve apices, 4-6 in $10 \mu \mathrm{m}$. Striae occasionally parallel throughout. Interstriae of equal or greater width than striae.

Distribution: Pinnularia borealis var. borealis has a wider distribution in Macedonia in comparison to the remaining taxa from the section Distantes of the genus Pinnularia. It was observed in western Macedonia on Šar Planina and Jablanica mountains, in south-western Macedonia on Mt. Pelister and in the spring area of River Brajcinska, and in central Macedonia near the city of Prilep.

On Mt. Šar Planina P. borealis var. borealis was found in various habitats, glacial lakes, streams and peat bogs. It was observed as epiphytic on macrophytes from glacial Golemo Karanikoličko Lake, at an altitude of ca. $2300 \mathrm{~m}$ a.s.l. At about the same altitude, $2320 \mathrm{~m}$ a.s.l., this taxon was found in a mixed sample of organic sediment and green algal filaments from a small lake near Čardak. It was further observed within the epipelon of glacial Lake Crno, located at an altitude of $2165 \mathrm{~m}$ a.s.l. and as epiphytic on macrophytes from a stream above Lake Crno at an altitude of about $2200 \mathrm{~m}$ a.s.l. On Mt. Jablanica this taxon was observed as an epiphyte on mosses from a peat bog above glacial Lake Podgorečko, at ca. $2000 \mathrm{~m}$ a.s.l.

Pinnularia borealis var. borealis was found on Mt. Pelister as epiphytic on mosses from the temporary lake Bolnici I near glacial Lake Golemo, at $2225 \mathrm{~m}$ a.s.l. It was also observed within the epipelon of the same lake. This taxon was found as epiphytic on mosses from the spring area of River Brajčinska, the largest tributary to Lake Prespa.

In the central part of Macedonia this taxon was found in a sample from the organic sediment of an old well, nearly $2 \mathrm{~m}$ deep, in the village of Zabrčani, near the city of Prilep. This well had been used as a drinking water supply at earlier times.

Observations: The wide distribution of $P$. borealis var. borealis was noted earlier, and its occurrence observed in a variety of aerial habitats, as well as in river and lake ecosystems (Krammer [7]). The occurrence of this taxon in a variety of habitats was also observed in Macedonia. The taxonomy around $P$. borealis var. borealis is thoroughly explained by Krammer [7].

More recently described $P$. sylviae Van de Vijver in Van de Vijver et al. [14] from Ile Amsterdam does resemble $P$. borealis var. borealis in the shape of the valve and the orientation and density of the striae. Nevertheless, the valves of $P$. sylviae are longer $(\mathrm{L}=42-80 \mu \mathrm{m})$ and the valve apices are slightly tapering, whereas the valve apices in P. borealis var. borealis are simple rounded.

\section{Pinnularia borealis var. scalaris (Ehrenberg) Rabenhorst [31] (Figs 10: 1-16)}

Valves linear to linear-lanceolate, with parallel or weakly convex margins and weakly protracted, rounded apices. Valve length 34.5-51.0 $\mu \mathrm{m}$, and valve width $8.0-10.0 \mu \mathrm{m}(\mathrm{n}=45)$. Axial area narrow to broad, $1 / 4$ to $1 / 6$ of valve width, linear and expanded near central area or lanceolate and gradually widening towards central area. Central area rhombic-lanceolate to rectangular, 1/2 of valve width or wider, rarely narrower. Central area vaguely defined, bordered on each side by 1-3 shortened striae. Raphe weakly lateral, outer raphe fissures linear to weakly curved, and inner fissures linear. Raphe rarely strongly lateral. Proximal raphe endings deflected towards one valve side, terminated with large and distinct, tear-drop shaped central pores. Distal raphe fissures sickle-shaped, positioned in small terminal areas, clearly discernible in LM. Transapical striae broad, rarely narrow, mostly distantly spaced. Striae radiate in mid-valve becoming parallel to weakly convergent near valve apices, 4-7 in $10 \mu \mathrm{m}$. Interstriae of equal or greater width than striae, rarely narrower.

Distribution: Pinnularia borealis var. scalaris was found on Pelister and Šar Planina mountains and in the region of Mariovo. On Mt. Pelister it was observed as epiphytic on mosses from the temporary lake Bolnici I near glacial Lake 
Golemo, at $2225 \mathrm{~m}$ a.s.l. On Mt. Šar Planina, $P$. borealis var. scalaris was found within the epipelon of Karanikoličko Lake (2185 m a.s.l.) and Lake Crno (2165 m a.s.l.). It was also observed as an epiphyte on the macrophyte vegetation from a stream above Lake Crno. At somewhat higher altitude, $2320 \mathrm{~m}$ a.s.l., this taxon was found in a mixed sample of organic sediment and green algal filaments from a small lake near Čardak, on Mt. Šar Planina. In the region of Mariovo, central Macedonia, $P$. borealis var. scalaris was observed as epiphytic on macrophytes from a wet rock before the village of Dunje.

Observations: Longer valves of $P$. borealis var. scalaris might be confused with $P$. sylviae, which is described from and restricted in distribution to Ile Amsterdam, southern Indian Ocean (Van de Vijver et al. [14]). A distinction can be made due to the slightly protracted valve apices in $P$. borealis var. scalaris. Shorter valves of $P$. borealis var. scalaris have more lanceolate valves with weakly convex margins (opposite to the strictly linear valves with parallel margins in P. sylviae).

\section{Pinnularia borealis var. islandica Krammer [7] (Figs 11: 1-13)}

Valves linear-elliptic, with weakly convex margins and unprotracted, broadly rounded apices. Valve length $25.0-47.5 \mu \mathrm{m}$, and valve width 9.5$13.0 \mu \mathrm{m}(\mathrm{n}=40)$. Axial area broad, rarely narrow, $1 / 4$ to $1 / 6$ of valve width, linear and expanded near central area or lanceolate and gradually widening towards central area. Central area large rhombiclanceolate to lanceolate, $1 / 2$ of valve width or wider, occasionally expanded close to valve margins. Central area mostly well defined, bordered on each side by 1-3 shortened striae. Raphe weakly lateral, outer raphe fissures linear to weakly curved, and inner fissures linear. Proximal raphe endings deflected towards one valve side, terminated with large and distinct, round to tear-drop shaped central pores. Distal raphe fissures sickle-shaped, positioned in prominent terminal areas, clearly discernible in LM. Transapical striae broad, mostly closely spaced, radiate in mid-valve becoming parallel near valve apices, 4-6 in $10 \mu \mathrm{m}$. Striae occasionally nearly parallel in mid-valve or distantly spaced. Interstriae of equal or narrower width than striae, rarely wider.

Distribution: Pinnularia borealis var. islandica was observed on Pelister and Šar Planina mountains and in the region of Mariovo. On Mt. Pelister it was found as an epiphyte on mosses from the temporary lake Bolnici I, located at an altitude of $2225 \mathrm{~m}$ a.s.l. near the glacial Lake Golemo. On Mt. Šar Planina this species was found at slightly higher altitude, ca. $2500 \mathrm{~m}$ a.s.l. within the epipelon of the spring of River Pena. In Mariovo, $P$. borealis var. islandica was observed in an aerial habitat, as an epiphyte on the macrophyte vegetation of a wet rock before the village of Dunje.

Observations: Pinnularia borealis var. islandica was described from Gullfoss, Iceland and is distributed in the subarctic region (Krammer [7]). Most of the valves depicted herein are shorter than the valve length given in the protologue of this taxon. Nevertheless, sufficient characters for a distinction from $P$. borealis var. islandica were not observed. We surmise that this taxon has a wider distribution in Europe, but was somehow overlooked or maybe misidentified in the past.

Pinnularia borealis var. islandica resembles $P$. sylviae Van de Vijver in Van de Vijver et al. [14] with regard to the orientation and density of the striae and the shape of the valve apices (broadly rounded and unprotracted in both taxa). A distinction can be made due to the shape of the valve (strictly linear with parallel margins in $P$. sylviae) and the axial area (narrow linear in $P$. sylviae compared to broadly linear or lanceolate in P. borealis var. islandica).

\section{Pinnularia borealis var. subislandica Krammer [7] (Figs 12: 1-27)}

Valves linear-lanceolate, with weakly convex margins and not or weakly protracted, truncate apices. Valve length $22.5-42.5 \mu \mathrm{m}$, and valve width 7.0-9.0 $\mu \mathrm{m}(\mathrm{n}=60)$. Axial area broad, $1 / 3$ to $1 / 5$ of valve width, linear and expanded near central area or lanceolate and gradually widening towards central area. Axial area rarely narrow, 1/8 of valve width. Central area rhombic-lanceolate to rounded, $1 / 2$ of valve width or wider, narrower only in shortest specimens. Central area mostly well defined, bordered on each side by 1-2 shortened striae. Central area occasionally vaguely defined. Raphe weakly lateral, outer raphe fissures linear to weakly curved, and inner fissures linear. Proximal raphe endings deflected towards one valve side, terminated with large and distinct, round to teardrop shaped central pores. Distal raphe fissures sickle-shaped, positioned in small terminal areas, clearly discernible in LM. Transapical striae broad, rarely narrow, mostly distantly spaced, occasionally closely spaced. Striae radiate in mid-valve becoming parallel to weakly convergent near valve apices, 4-6 in $10 \mu \mathrm{m}$. Interstriae of equal or greater width than striae, rarely narrower. 
Distribution: Pinnularia borealis var. subislandica was found on Mt. Šar Planina, western Macedonia, Mt. Pelister, south-western Macedonia and in the region of Mariovo and near the city of Prilep in central Macedonia. On Mt. Pelister this taxon was observed as epiphytic on mosses from the temporary Lake Bolnici I, near glacial Lake Golemo, at $2225 \mathrm{~m}$ a.s.l.

On Mt. Šar Planina $P$. borealis var. subislandica was observed within the epipelon of Lake Golemo Karanikoličko (at 2185 m a.s.l.) and Lake Crno (at $2165 \mathrm{~m}$ a.s.1.). This taxon was also found as epiphytic on the macrophyte vegetation from a stream above Lake Crno and from Lake Golemo Karanikoličko.

In central Macedonia $P$. borealis var. subislandica was found in the region of Mariovo as epiphyte on macrophytes from a wet rock before the village of Dunje and in a sample of the organic sediment of an old well in the village of Zabrčani, near the city of Prilep.

Observations: The valve width for $P$. borealis var. subislandica given in the protologue ( $\mathrm{W}=9.4-11.5 \mu \mathrm{m}$ ) is slightly higher than observed herein. The truncate valve apices, also observed in the specimens from Macedonia, distinguish this taxon from the remaining varieties within $P$. borealis (Krammer [7]).

In general, it is difficult to differentiate the infraspecific taxa from the $P$. borealis complex: var. borealis, var. islandica, var. scalaris and var. subislandica. All of these taxa share linear-elliptic or linear-lanceolate valves, with narrow to moderately broad axial area, more or less rhombiclanceolate central area and rather equal striae orientation and density. Nevertheless, a distinction was made due to the shape of the valve apices. Both $P$. borealis var. borealis and $P$. borealis var. islandica have unprotracted valve ends, but the valve apices in the latter one are particularly broader rounded. Pinnularia borealis var. scalaris can be distinguished by the weakly protracted valve apices, whereas $P$. borealis var. subislandica by the truncate valve apices.

The difficulties around the identification of the $P$. borealis taxa were recently also outlined by Souffreau et al. [18]. The authors studied $52 P$. borealis strains from different geographical regions (South and North America, Antarctica, Europe), which included three morphological varieties: var. borealis, var. islandica and var. scalaris. Identical eight lineages have been recovered by two different and independent markers, and a distinct continental Antarctic lineage has been evidenced. Only one morphological variety (var. islandica) has been restricted to a single lineage, whereas the other two have been scattered throughout the phylogeny. Furthermore, a reasonable doubt has been associated with the "identification based on valve morphology alone" for the examined species complexes, with methodologies like geometric morphometrics and DNA barcoding suggested as possible assistance (Souffreau et al. [18]). Nevertheless, regarding the $P$. borealis complex we decided to follow existing morphospecies concepts and use existing names. Molecular evidence for this complex from Macedonia is yet not available and the application of additional methodologies, which might prove helpful in identification, would require a rather different approach than the one adopted here.

\section{Pinnularia dubitabilis Hustedt var. dubitabilis [17] (Figs 4: 11-20)}

Valves rectangular, linear, with parallel to weakly convex margins and unprotracted, rounded to truncate apices. Valve length $28.0-40.0 \mu \mathrm{m}$, and valve width $7.0-8.5 \mu \mathrm{m}(\mathrm{n}=30)$. Axial area very broad, $1 / 2$ of valve width or wider, linear to lanceolate. Axial area rarely narrower, 1/4 of valve width, only in shortest specimens. Central area absent, rarely vaguely defined with 1-2 shortened striae from both sides. Raphe weakly lateral, outer raphe fissures linear to weakly curved, and inner fissures linear. Proximal raphe endings deflected towards one valve side, terminated with large and distinct, round to tear-drop shaped central pores. Distal raphe fissures sickle-shaped, clearly discernible in LM. Transapical striae broad, very short and marginal. Striae distantly spaced, parallel throughout, rarely becoming weakly convergent near valve apices, $4-5$ in $10 \mu \mathrm{m}$. Interstriae of equal or greater width than striae.

Distribution: Pinnularia dubitabilis var. dubitabilis was observed in aerial habitats on mountain of Osogovo and in the region of Mariovo, and in various habitats, glacial lakes and peat bogs, on Mt. Šar Planina. On Mt. Osogovo, eastern Macedonia, it was found in a mixed sample of mosses and algal filaments from a wet rock near Stari Grad. In the region of Mariovo, central Macedonia, this taxon was observed as epiphytic on macrophytes from a wet rock before the village of Dunje.

On Mt. Šar Planina P. dubitabilis var. dubitabilis was observed on several localities: Lakes Belo and Golemo Karanikoličko and a peat bog near Ceripašina. Lake Belo is located at an altitude of $2265 \mathrm{~m}$ a.s.l. in a rocky basin surrounded by grassland, and is fed by several streams as well as the snow-melt and rain fall. Pinnularia dubitabilis var. dubitabilis 
was observed within the epipelon of Lake Belo. This taxon was found as an epiphyte on the macrophyte vegetation from Lake Golemo Karanikoličko, located at an altitude of ca. $2300 \mathrm{~m}$ a.s.l. At somewhat lower altitude, $2150 \mathrm{~m}$ a.s.l. this taxon was observed as epiphytic on mosses from a peat bog near Ceripašina.

Observations: A single specimen of $P$. dubitabilis var. minor is depicted in Krammer [7]. It is distinguished from the nominate variety by the very short and marginally positioned striae. The valve size given in the protologue (length $=20.0$ $25.0 \mu \mathrm{m}$, width $=6.5-6.8 \mu \mathrm{m}$ ) is overlapping with the valve size of the nominal variety (length $=$ $23.0-40.0 \mu \mathrm{m}$, width $=6.0-7.0 \mu \mathrm{m})$. According to Krammer [7] P. dubitabilis var. dubitabilis was not observed in Europe. However, there are few other records of this taxon from elsewhere under different names as $P$. borealis $\mathrm{f}$. rectangularis Carlson, $P$. borealis var. rectangulata Hustedt or $P$. eburnea (Carlson) Zanon.

However, sufficient morphological differences to distinguish the specimens depicted here from $P$. dubitabilis var. dubitabilis are not present.

\section{Key for identification of Pinnularia section Distantes from Macedonia}

1. Valve wider than $20 \mu \mathrm{m}$

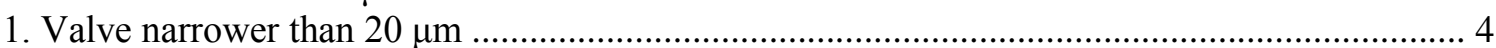

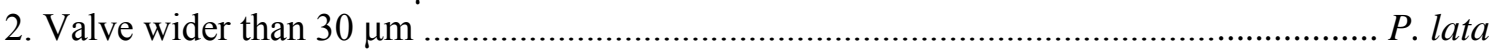

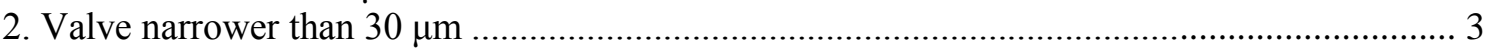

3. Valve longer than $80 \mu \mathrm{m}$, ornamentation on valve face present ............................ P. micevskii

3. Valve shorter than $80 \mu \mathrm{m}$, ornamentation on valve face absent .......................... P. subalpina

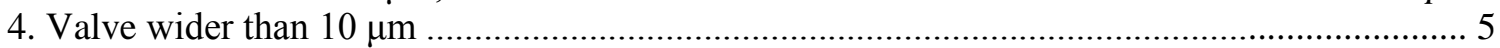

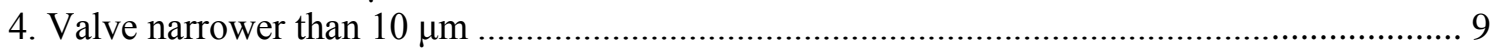

5. Valve apices protracted ......................................................... P. rabenhorstii var. franconica

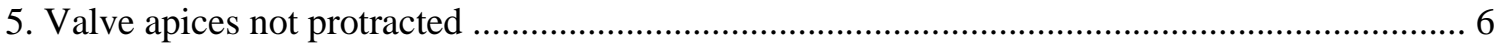

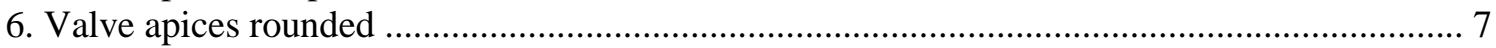

6. Valve apices truncate .......................................................... P. rabenhorstii var. rabenhorstii

7. Valves linear, with consistently parallel margins ..................................................... P. idsbensis

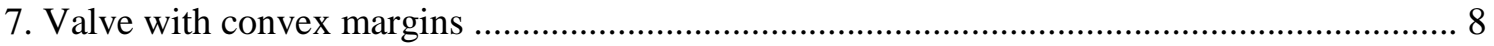

8. Valves linear-elliptic, valve apices narrowly rounded .................................. P. lata var. minor

8. Valves linear-lanceolate, apices broadly rounded .............................. P. borealis var. islandica

9. Valves rectangular, striae very short .............................................................. P. dubitabilis

9. Valves linear to linear lanceolate, axial area narrow .............................................................. 10

10. Valve apices truncate ........................................................ P. borealis var. subislandica

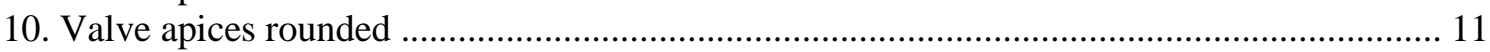

11. Valve apices weakly protracted ...................................................... P. borealis var. scalaris

11. Valve apices not protracted ............................................................ P. borealis var. borealis 


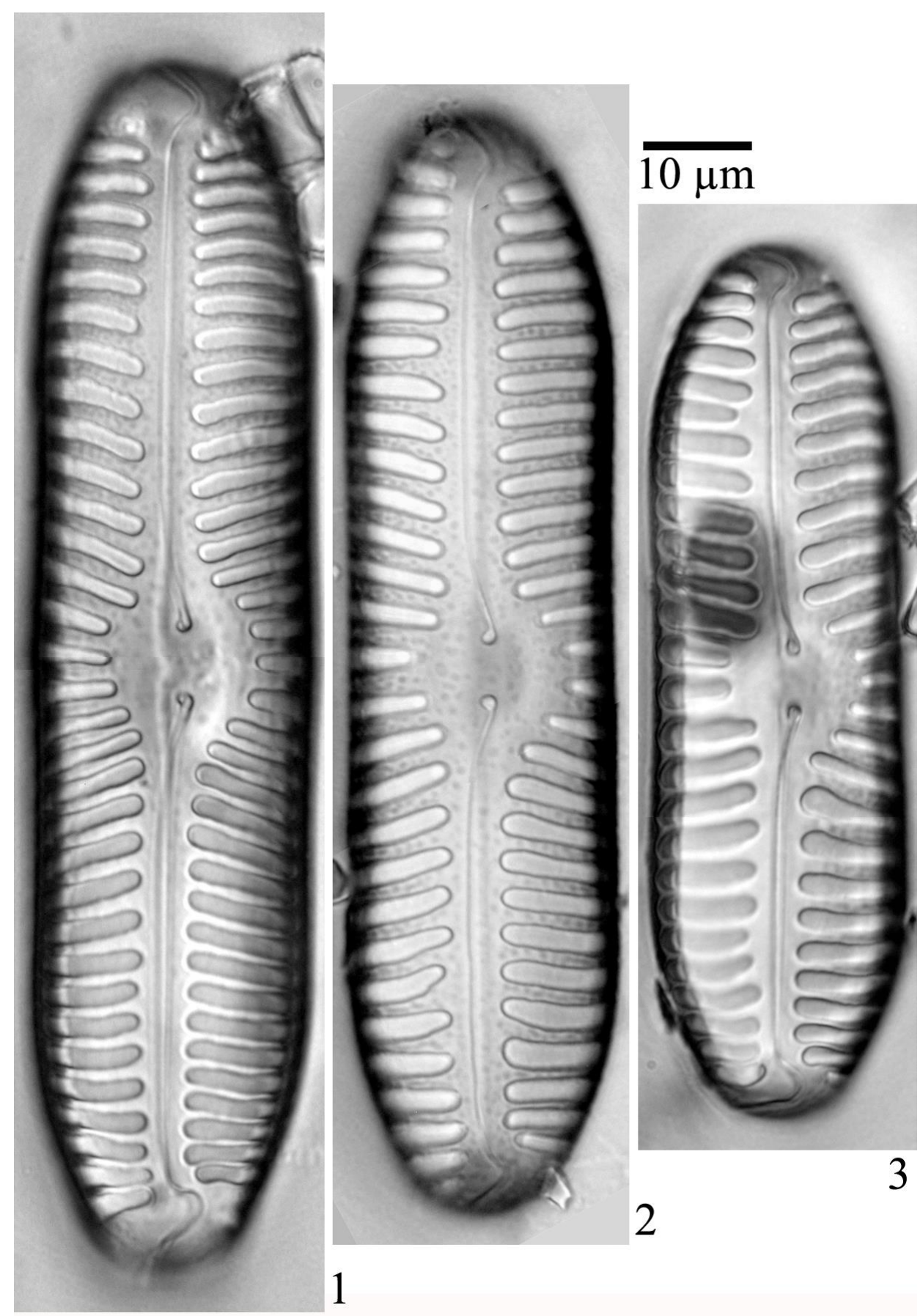

PLATE 1. Figures 1-3: Pinnularia micevskii Levkov, Pavlov \& Nakov sp. nov. (type population). Figure 1: 1 representing the holotype. Scale bar $=10 \mu \mathrm{m}$. Figures 1-3: Mt. Šar Planina 


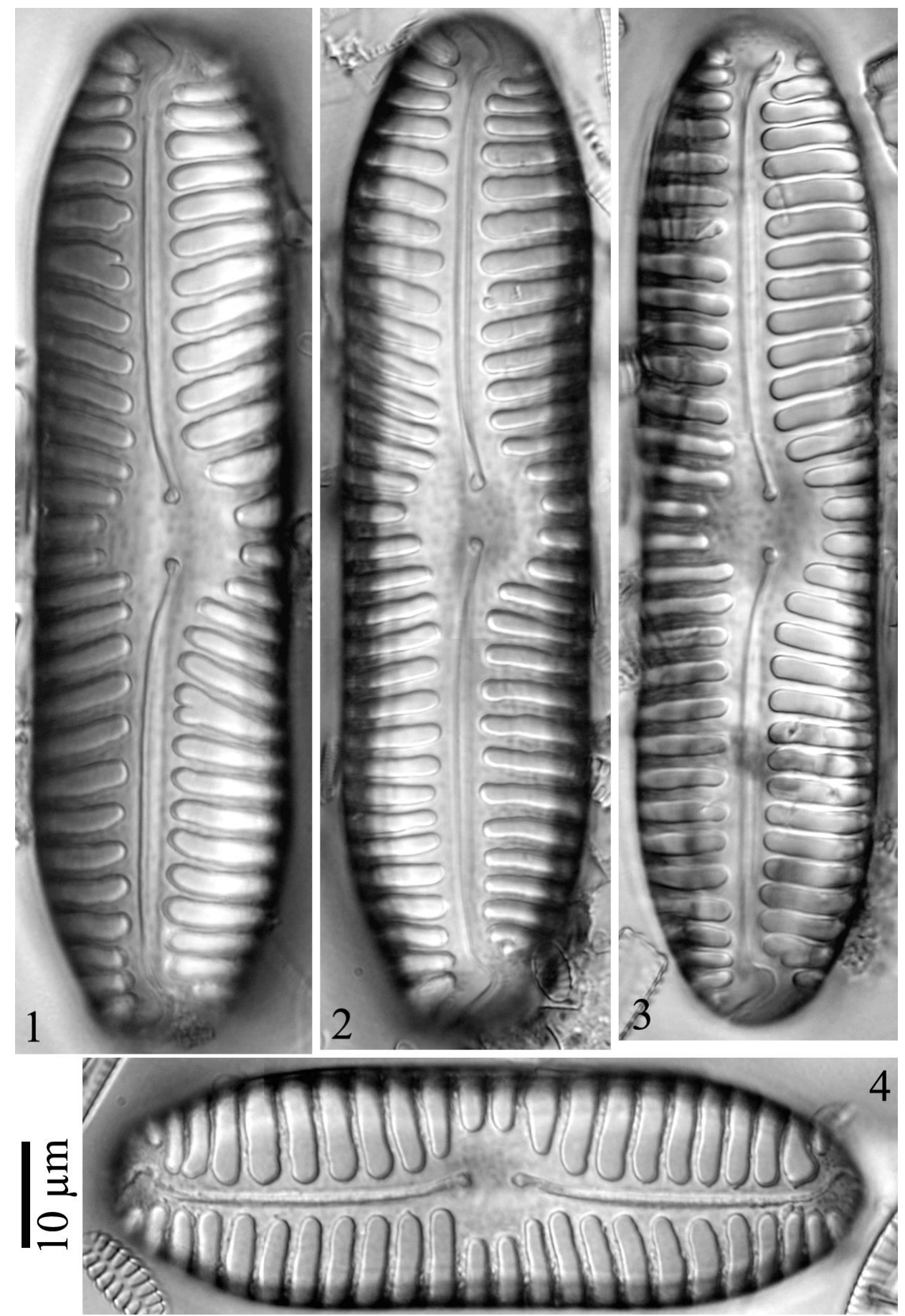

PLATE 2. Figures 1-4: Pinnularia micevskii Levkov, Pavlov \& Nakov sp. nov. Scale bar $=10 \mu \mathrm{m}$. Figures 1-4: Mt. Jablanica 

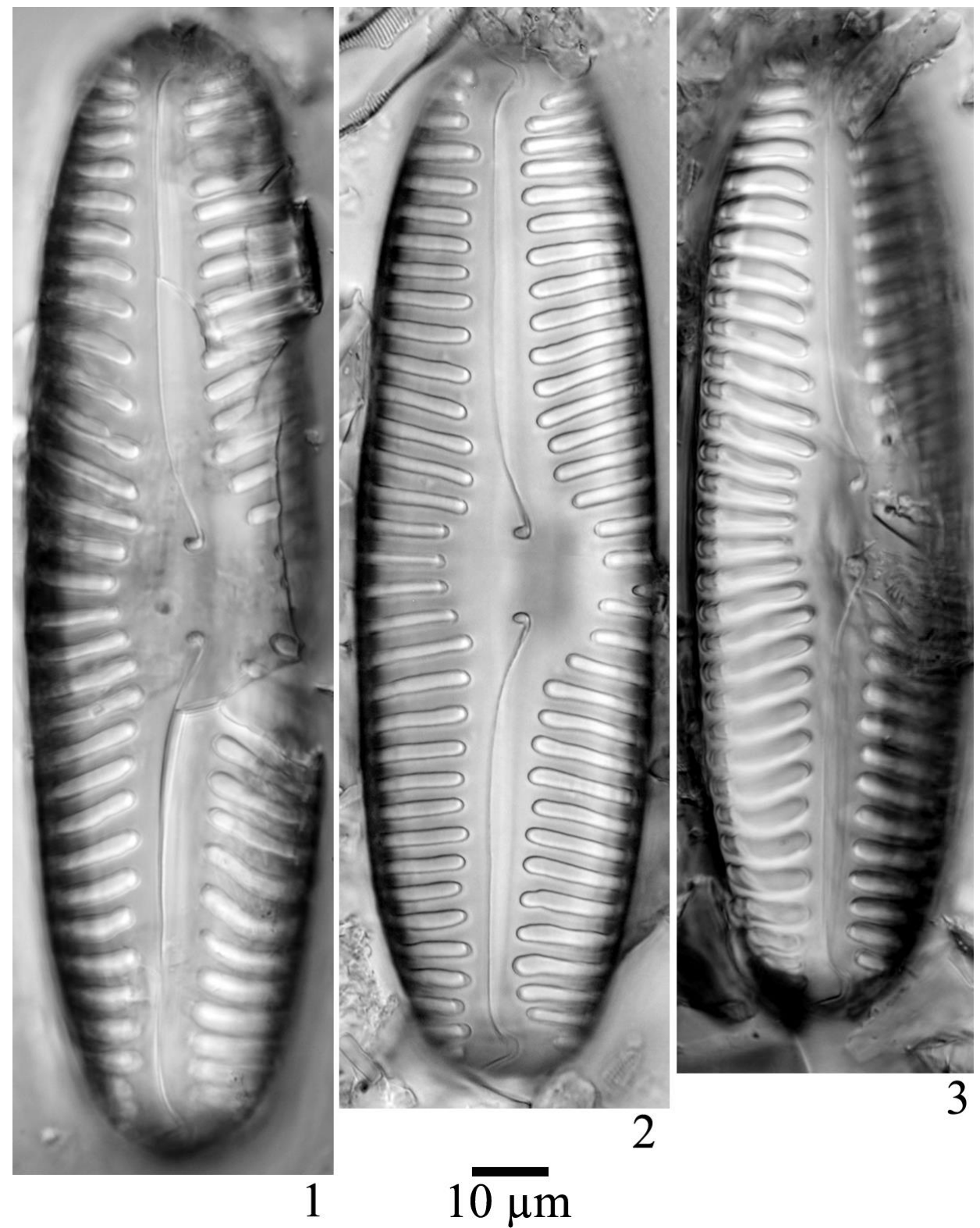

PLATE 3. Figures 1-3: Pinnularia lata (Brébisson) Rabenhorst var. lata. Scale bar $=10 \mu \mathrm{m}$. Figures 1-3: Mt. Šar Planina 

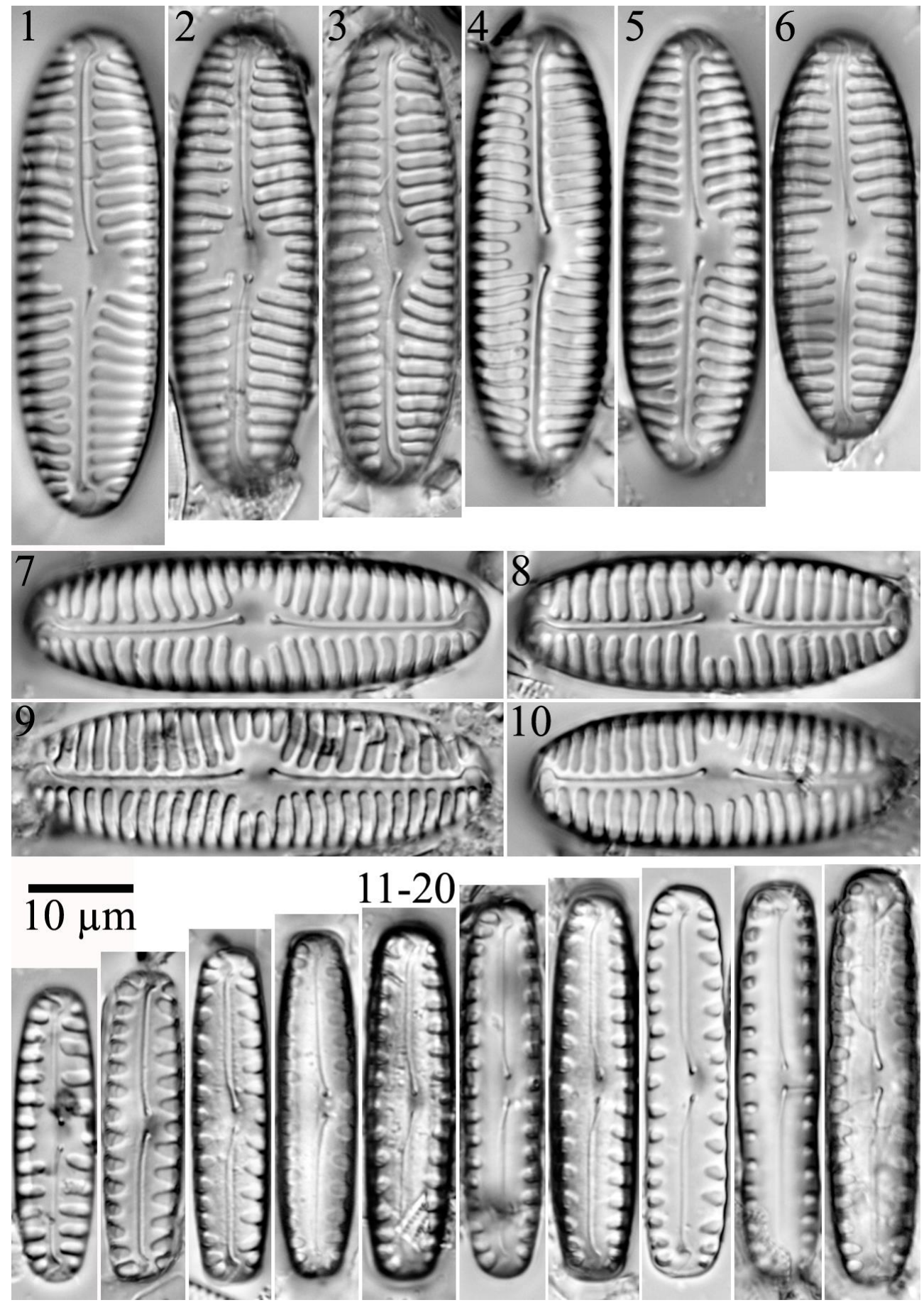

PLATE 4. Figures 1-10: Pinnularia lata var. minor (Grunow) Cleve. Figures 11-20:

Pinnularia dubitabilis Hustedt var. dubitabilis. Scale bar $=10 \mu \mathrm{m}$. Figures: 1-10, 12-16, 20. Mt. Šr Planina. Figure 11: Mariovo. Figures 17-19: Mt. Osogovo 


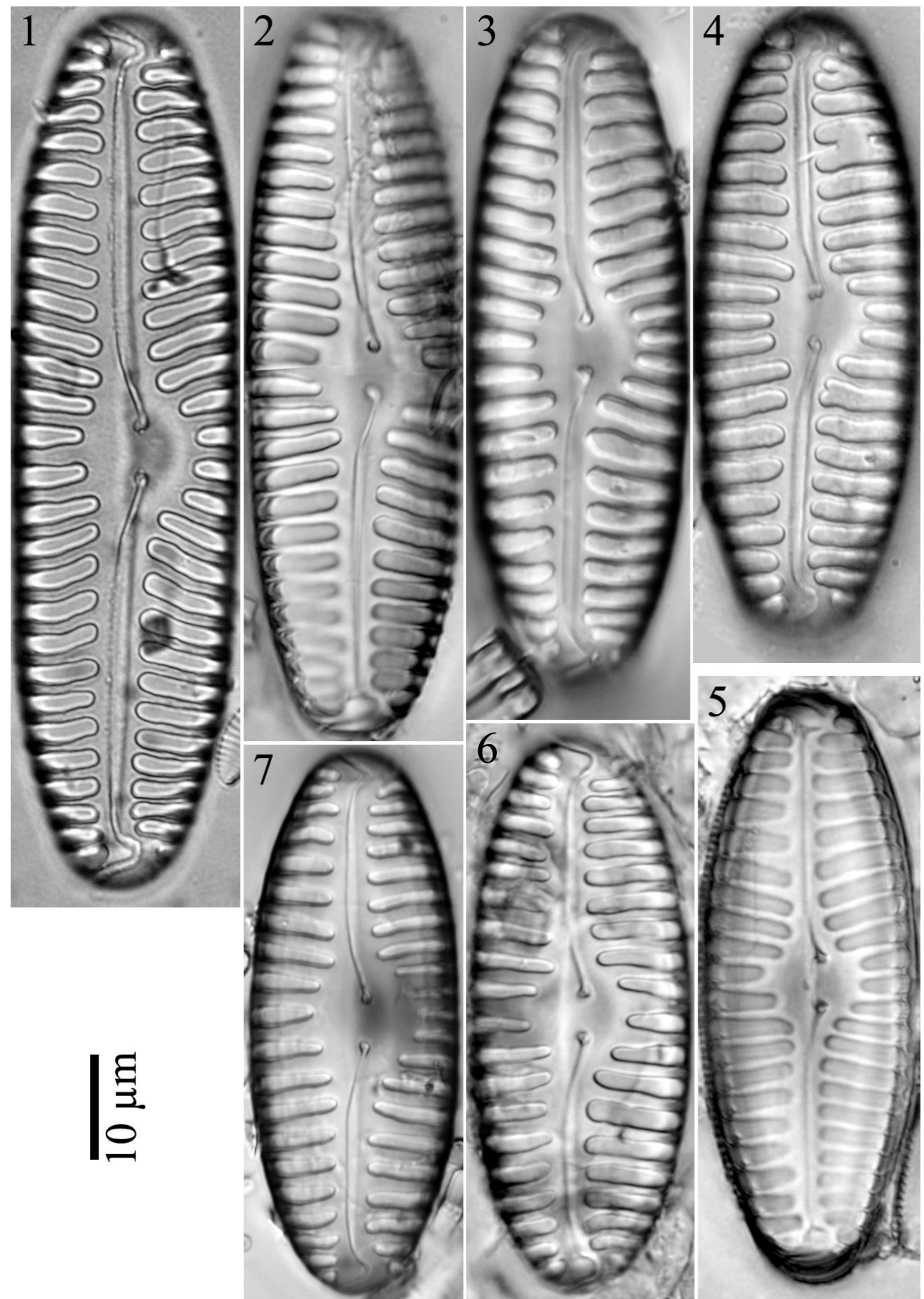

PLATE 5. Figures 1-7: Pinnularia subalpina sp. nov. (type population).

Figure 5: 3 representing the holotype. Scale bar $=10 \mu \mathrm{m}$. Figures 1-4: Lake Crno, Mt. Sar Planina. Figures 5-7: Small lake near Čardak, Mt. Šar Planina 

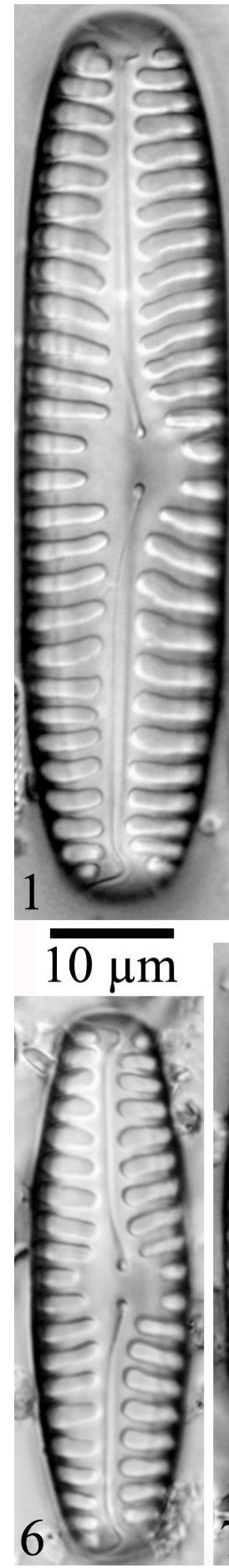
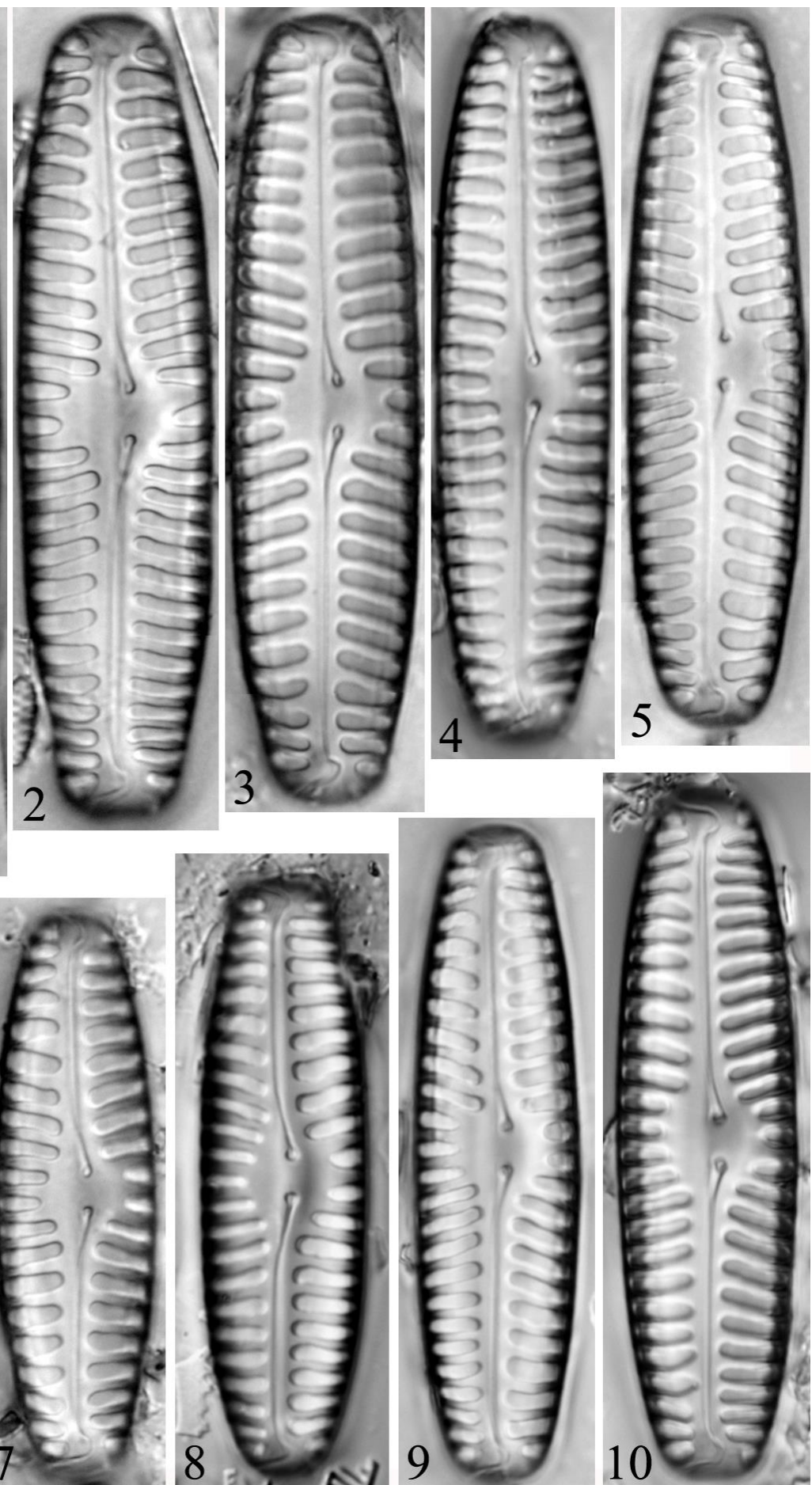

PLATE 6. Figures 1-10: Pinnularia rabenhorstii (Grunow) Krammer var. rabenhorstii. Scale bar $=10 \mu \mathrm{m}$. Figures 1-5, 8, 9: Mt. Šar Planina. Figure 10: Mt. Pelister 

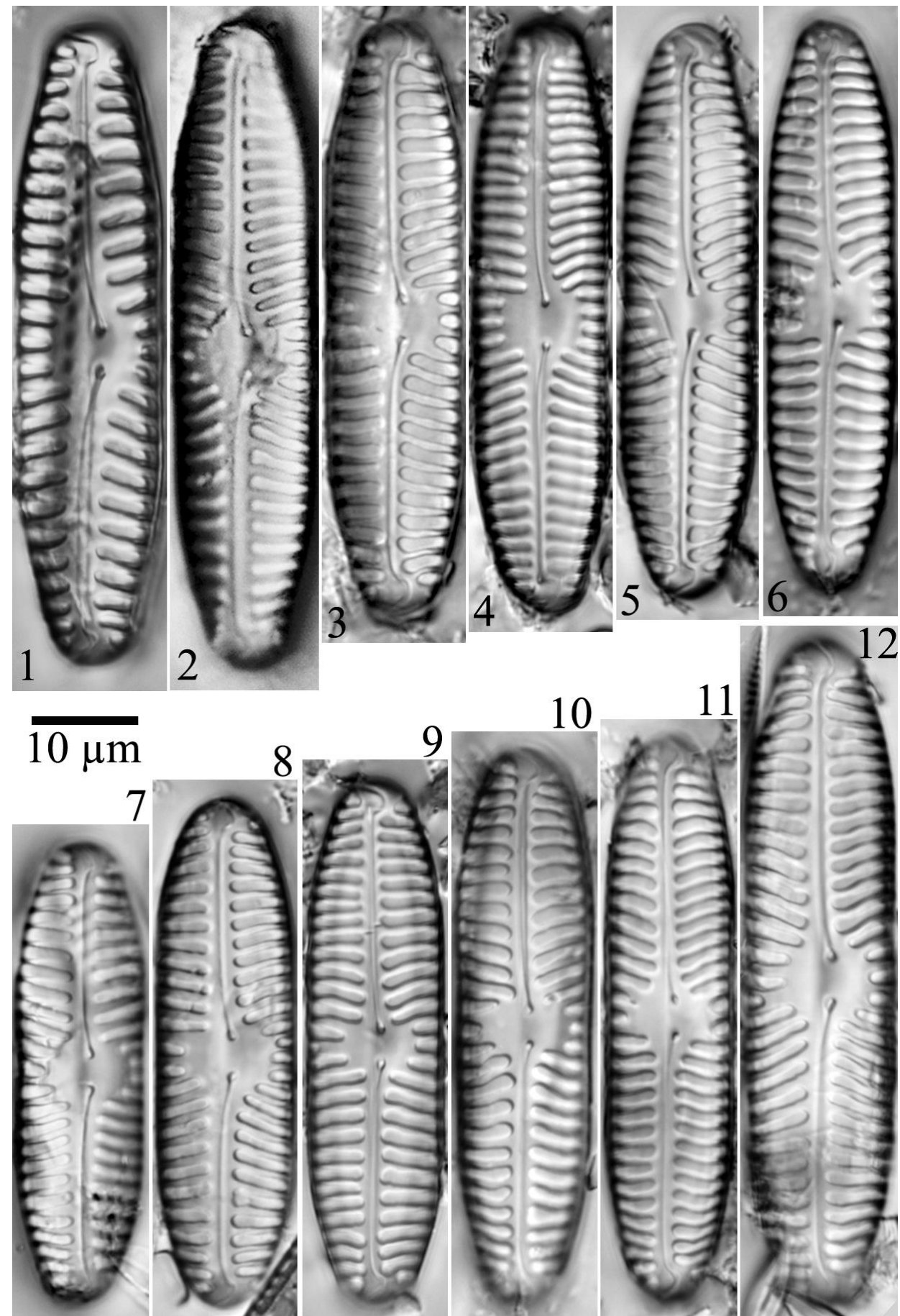

PLATE 7. Figures 1-12: Pinnularia rabenhorstii var. franconica Krammer. Scale bar $=10 \mu \mathrm{m}$.

Figure 1: Mariovo. Figures 2, 3, 5, 6: Mt. Šar Planina. Figures: 4, 7-12. Mt. Pelister 


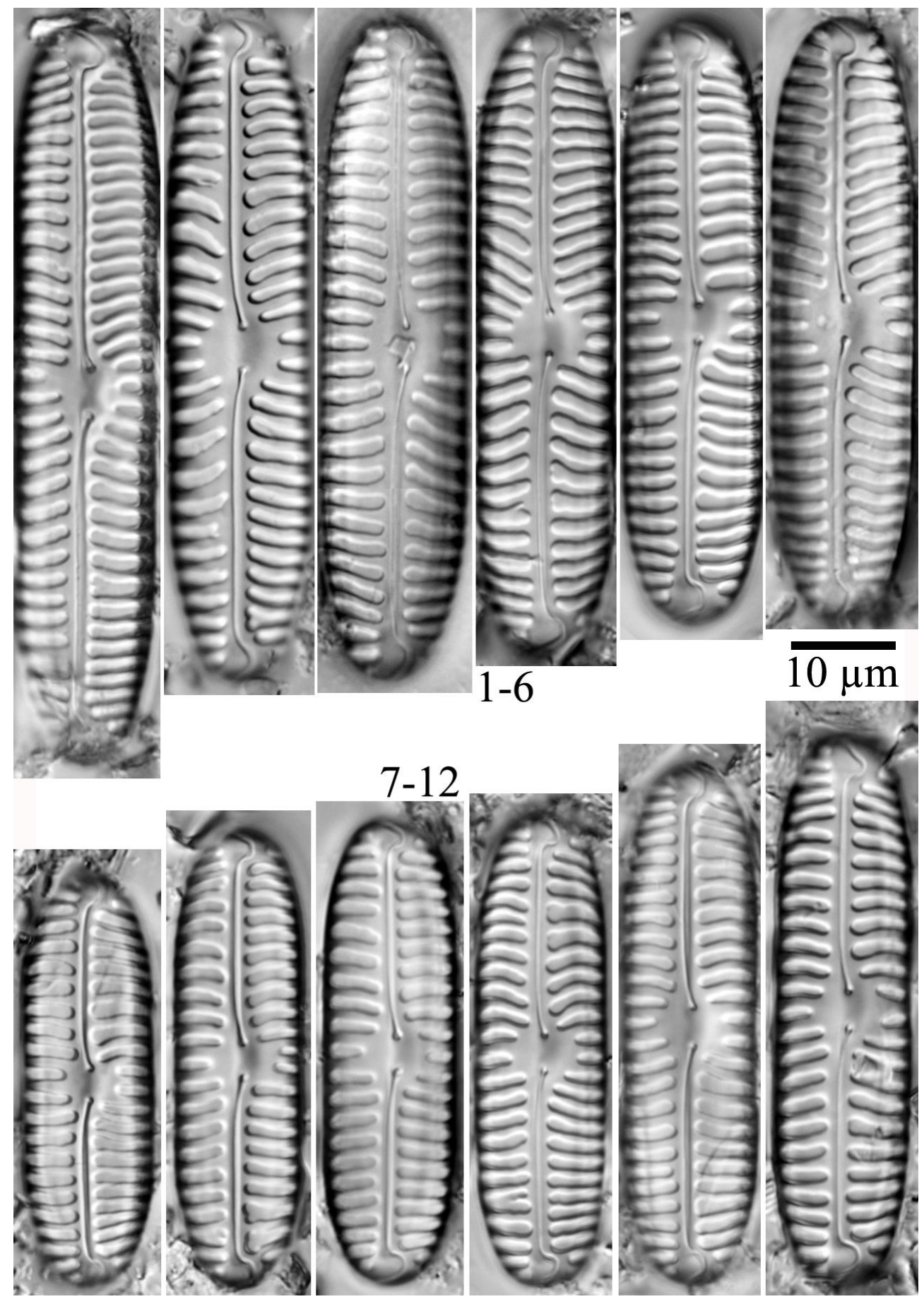

PLATE 8. Figures 1-12: Pinnularia idsbensis sp. nov. (type population).

Figure 8: 2 representing the holotype.Scale bar $=10 \mu \mathrm{m}$. Figures 1, 2, 4, 5, 7-12: Mt. Pelister. Figures 3, 6: Mt. Šar Planina 


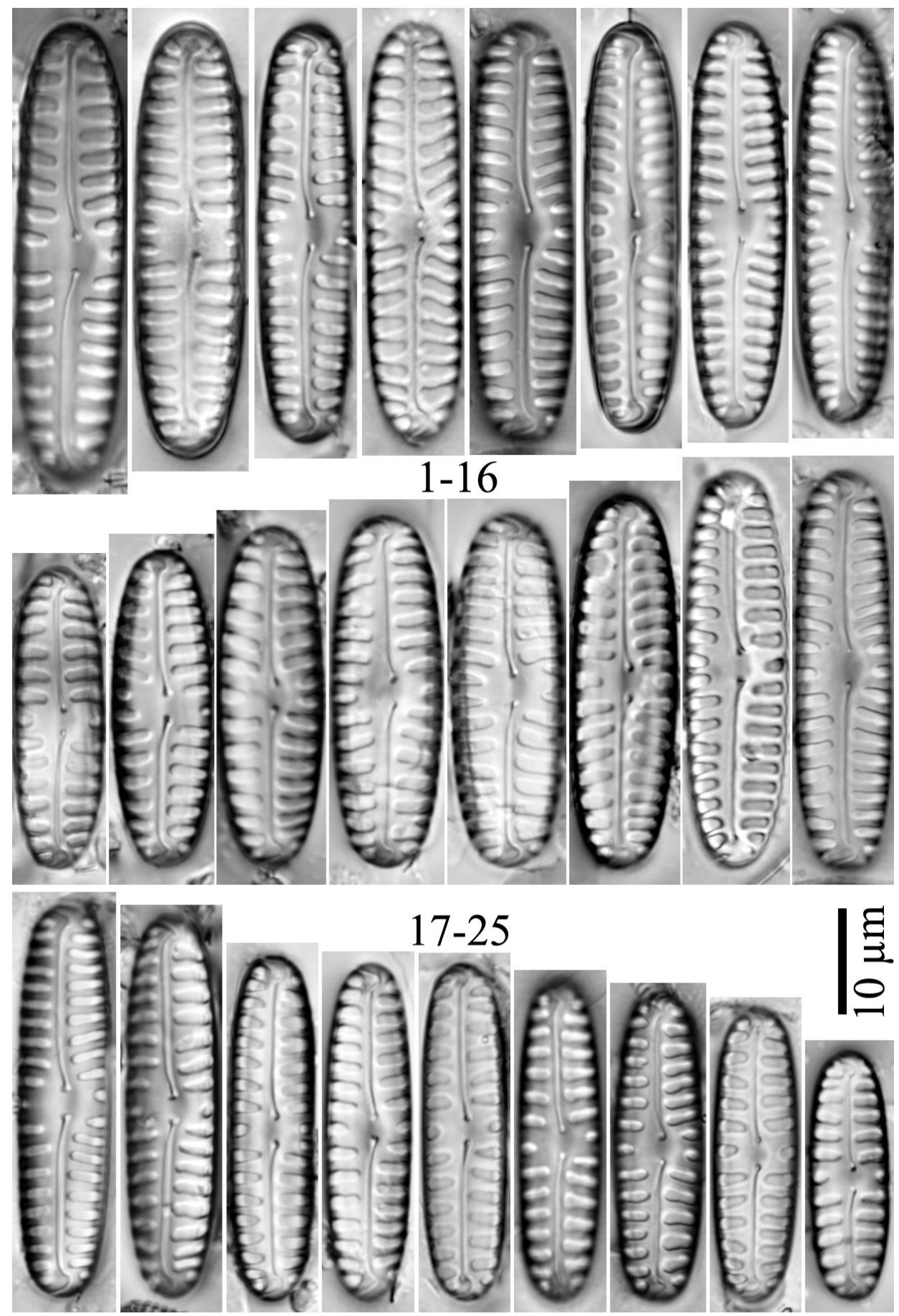

PLATE 9. Figures 1-25: Pinnularia borealis Ehrenberg var. borealis. Scale bar $=10 \mu \mathrm{m}$. Figures 1-5, 11, 14, 25: Mt. Šar Planina. Figures 15, 16: Mt. Jablanica.

Figures 6-10, 12, 13, 17-24: Mt. Pelister 


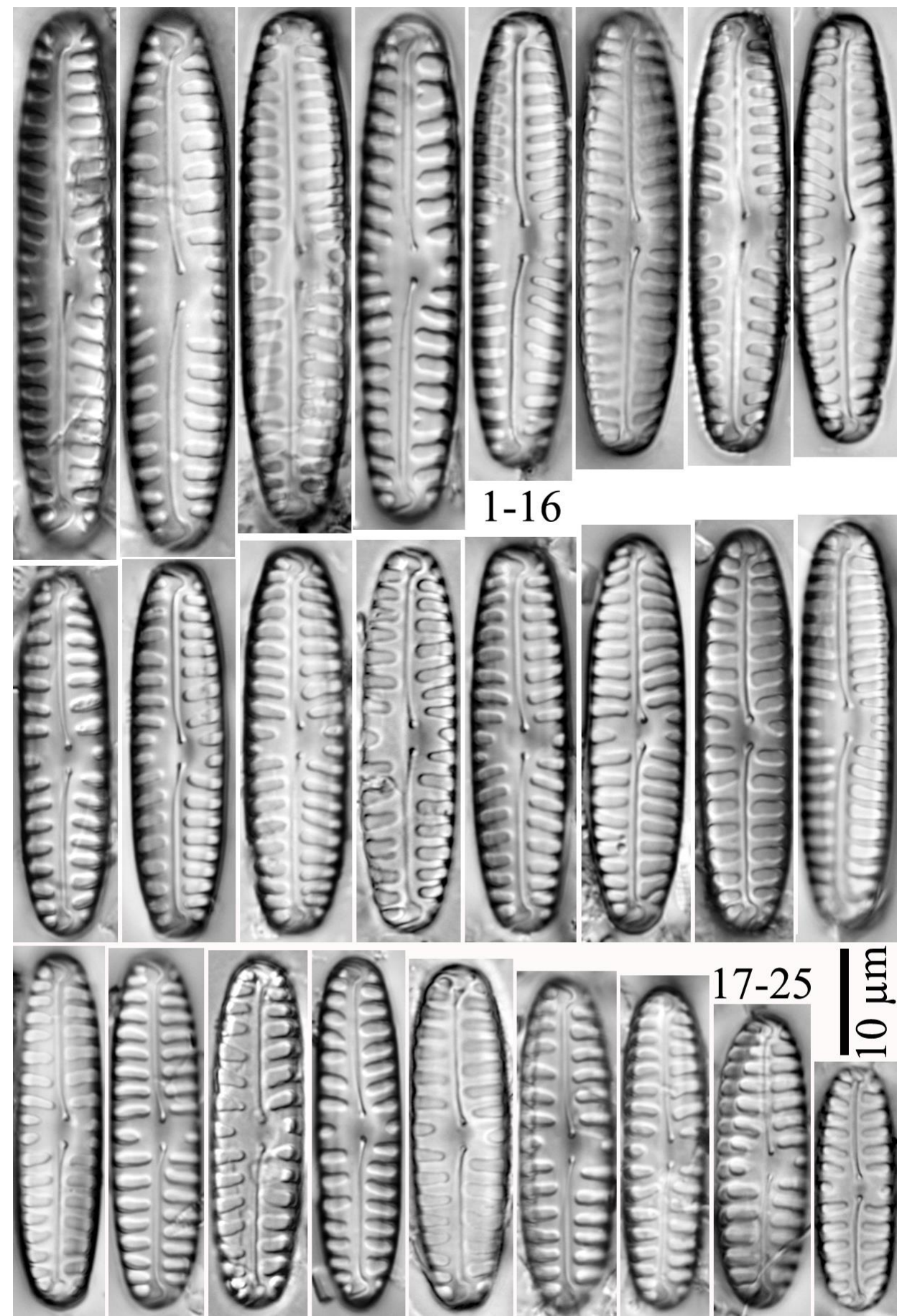

PLATE 10. Figures 1-16: Pinnularia borealis var. scalaris (Ehrenberg) Rabenhorst. Figures 17-25: Pinnularia borealis Ehrenberg var. borealis. Scale bar $=10 \mu \mathrm{m}$.

Figures 1-8, 11-13, 16: Mt. Šar Planina. Figures 9, 10, 17-25: Mt. Pelister. Figures 14, 15: Mariovo 

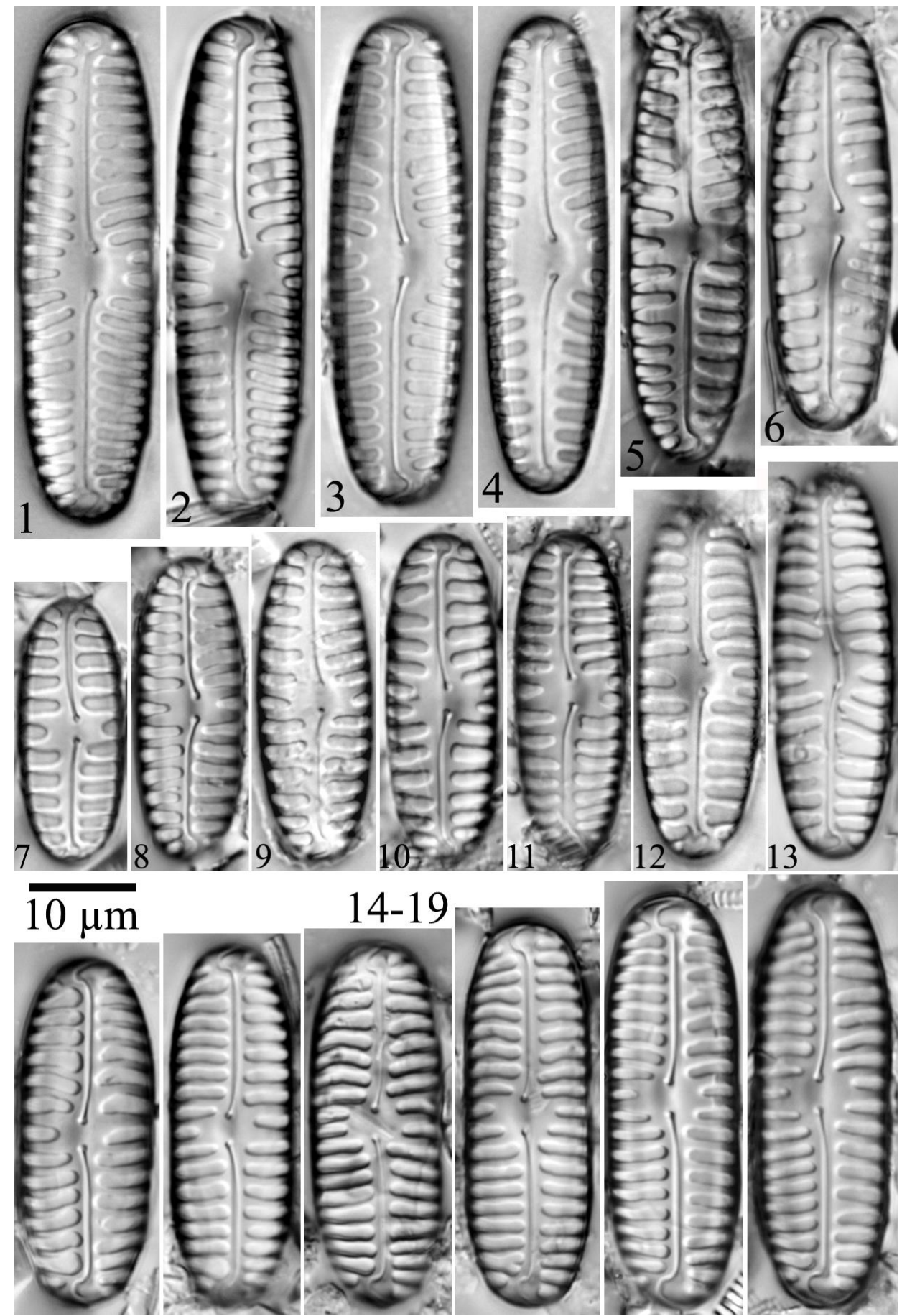

PLATE 11. Figures 1-13: Pinnularia borealis var. islandica Krammer.

Figures 14-19: Pinnularia idsbensis sp. nov. Scale bar $=10 \mu \mathrm{m}$. Figures 1, 3, 4, 6, 9, 12: Mt. Šr Planina. Figures 2, 5: Mariovo. Figures 7, 8, 10, 11, 13-19: Mt. Pelister 

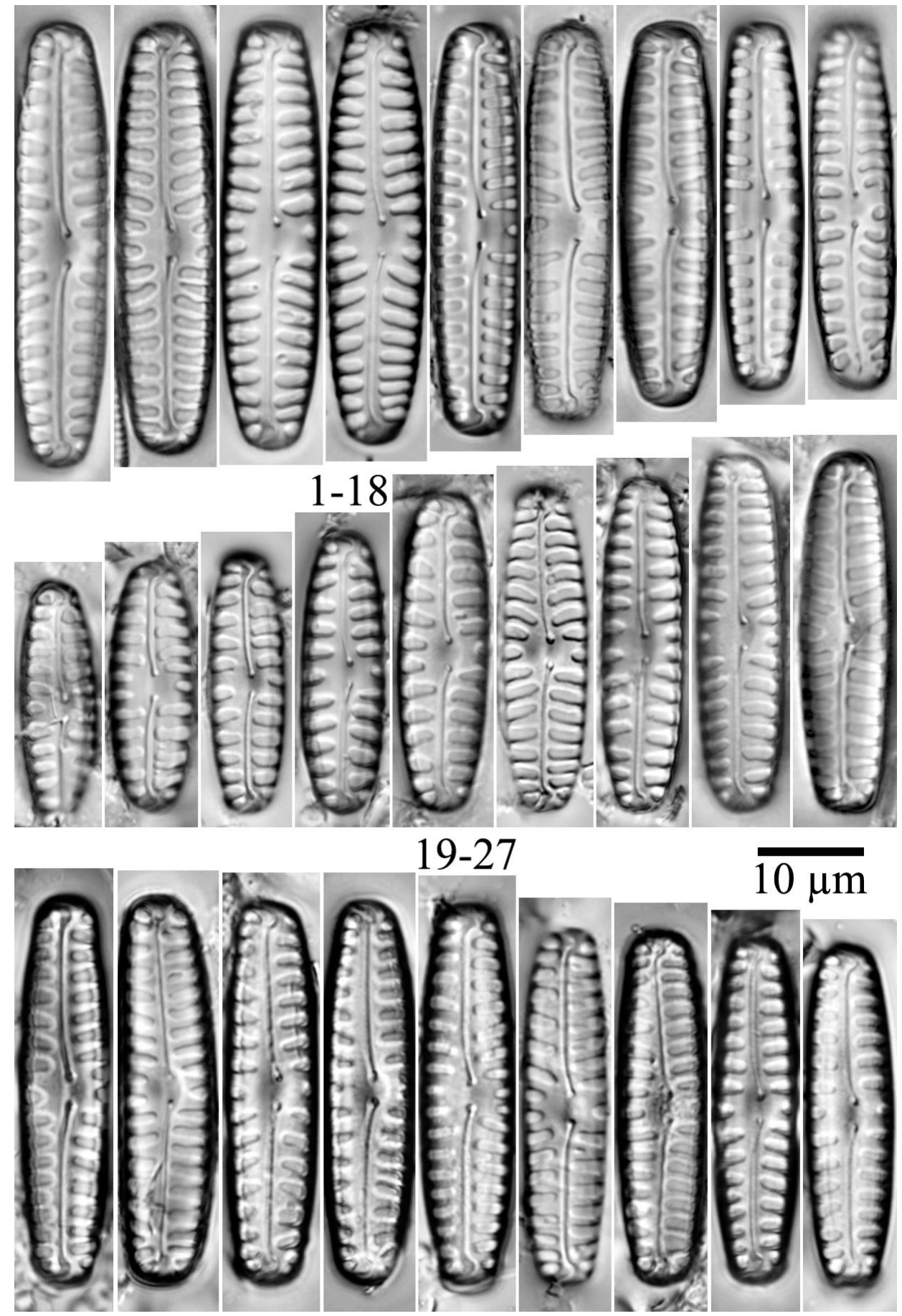

PLATE 12. Figures 1-27: Pinnularia borealis var. subislandica Krammer. Scale bar $=10 \mu \mathrm{m}$. Figures 1, 2, 5-11, 14, 19-27: Mt. Šar Planina. Figures 3, 4: Mariovo.

Figures 12, 15, 17: Mt. Pelister. Figures 13, 16, 18: Village of Zabrčani, near Prilep (old well) 
Acknowledgements: This study was partly supported by the Alexander von Humboldt Foundation from Germany.We are sincerely grateful to Luc Ector for providing to us a lot of published information on Pinnularia and also to Ditmar Metzeltin for his useful comments and immeasurable help with the identification of the taxa. At the same time, our gratitude goes to IDSB (Biology Students' Research Society) for the massive contribution to the Macedonian National Diatom Collection, namely the large number of samples collected during the annual sampling campaigns organized by this Society.

\section{REFERENCES}

[1] R. Patrick, C. W. Reimer, The diatoms of the United States exclusive of Alaska and Hawai, Volume 1, Fragilariaceae, Eunotiaceae, Achnanthaceae, Naviculaceae, Monographs of the Academy of Natural Sciences of Philadelphia 13, 1966, pp. 1-688.

[2] C. G. Ehrenberg, Mitteilungen über zwei neue asiatische Lager fossiler Infusorien-Erden aus dem russischen Trans-Kaukasien (Grusien) und Sibirien, Ber. Bekanntm. Verh. Königl. Preuss. Akad. Wissensch. Berlin, (1843), pp. 43-49.

[3] P. T. Cleve, Synopsis of the Naviculoid diatoms, Kongliga Svenska Vetenskaps-Akademiens Handlingar 27, 1895, pp. 1-220.

[4] A. Mayer, Über den formenkreis von Pinnularia borealis Ehrbg. und Pinnularia lata (Bréb.) W. Smith, Ber. Naturw. Verein Regensburg 17 (1925), pp. 47-52.

[5] A. Schmidt et al., Atlas der Diatomaceenkunde, Aschersleben-Leipzig 1874-1959.

[6] K. Krammer, Die Gattung Pinnularia in Bayern, Hoppea, Denkschriften der Regensburgischen Botanischen Gesellschaft 52, Regensburg, 1992, pp. 1-304.

[7] K. Krammer, The genus Pinnularia, in: Diatoms of Europe, H. Lange-Bertalot (Ed.), A.R.G. Gantner Verlag K.G., Ruggell, 2000, pp. 1-703.

[8] D. Metzeltin, H. Lange-Bertalot, Tropical diatoms of South America, I. About 700 predominantly rarely known or new taxa representative of the neotropical flora, in: Iconographia Diatomologica, 5, H. Lange-Bertalot (Ed.), A.R.G. Gantner Verlag K.G., Ruggell, 1998, pp. 1-695.

[9] D. Metzeltin, H. Lange-Bertalot, Tropical diatoms of South America, II. Special remarks on biogeography disjunction, in: Iconographia Diatomologica 18, H. Lange-Bertalot (Ed.), A.R.G. Gantner Verlag K. G., Ruggell, 2007, pp. $1-877$.

[10] D. Metzeltin, H. Lange-Bertalot, S. Nergui, Diatoms in Mongolia, in: Iconographia Diatomologica 20, $\mathrm{H}$.
Lange-Bertalot (Ed.), A.R.G. Gantner Verlag K.G., Ruggell, 2009, pp. 1-686.

[11] B. Van de Vijver, Y. Frenot, L. Beyens, Freshwater diatoms from Ile de la Possession (Crozet Archipelago, Subantarctica), Bibliotheca Diatomologica 46, J. Cramer, Berlin, Stuttgart, 2002, pp. 1-412.

[12] B. Van de Vijver, Pinnularia obaesa sp. nov. and $P$. australorabenhorstii sp. nov., two new large Pinnularia (sect. Distantes) from the Antarctic King George Island (South Shetland Islands), Diat. Res. 23 (2008), pp. 221-232.

[13] B. Van de Vijver, R. Zidarova, Five new taxa in the genus Pinnularia sectio Distantes (Bacillariophyta) from Livingston Island (South Shetland Islands), Phytotaxa 24 (2011), pp. 39-50.

[14] B. Van de Vijver, B. Chattová, D. Metzeltin and M. Lebouvier, The genus Pinnularia (Bacillariophyta) on Ile Amsterdam (TAAF, South Indian Ocean), Nova Hedwigia, Beiheft 141 (2012), pp. 201-236.

[15] W. Bock, Distantes (Pinnularia - Bacillariophyceae), Eine kritische Zusammenstellung, Nachr. Naturwiss. Mus. Aschaffenburg 83 (1975), pp. 1-46.

[16] L. Rabenhorst, Die Süßwasser-Diatomaceen (Bacillarien) für Freunde der Mikroskopie, Eduard Kummer, Leipzig, 1853, pp. 1-72.

[17] F. Hustedt, Süßwasser-Diatomeen aus dem Albert-Nationalpark in Belgisch-Kongo, Expl. Park Nat. Albert 8 (1949), pp. 1-199.

[18] C. Souffreau, P. Vanormelingen, B. Van de Vijver, T. Isheva, E. Verleyen, K. Sabbe and W. Vyverman, Molecular Evidence for Distinct Antarctic Lineages in the Cosmopolitan Terrestrial Diatoms Pinnularia borealis and Hantzschia amphioxys, Protist 164 (2013), pp. 101-115.

[19] Z. Levkov, S. Krstic, T. Nakov, Lj. Melovski, Diatom assemblages on Shara and Nidze Mountains, Macedonia, Nova Hedw. 83 (2005), pp. 501-537.

[20] Lj. Petrovska, P. Stojanov, Algenata flora na karpite vo Makedonija (Algal flora of wet rocks in Macedonia), God. Zb. PMF, Skopje 27-28 (1975), pp. 161-168.

[21] Lj. Petrovska, P. Stojanov, Algenata flora vo ribnicite "Kamnik" - Skopsko (Algal flora of fishpond "Kamnik" - Skopje), God. Zb. Biol. 32 (1979), pp. 117-131.

[22] S. Krstic, P. Stojanovski, Comparative microflora analysis in mouth waters of River Bosava and Anska, Macedonia, God. Zb. Biol. 46 (1993), pp. 101-110.

[23] H. Heiden and R.W. Kolbe, Die Marinen Diatomeen der Deutschen Südpolar-Expedition, 19011903. In: Deutsche Sudpolar-Expedition, 19011903, herausgegeben von Erich von Drygalski 8 (1928), pp. 447-715. 
[24] R. Simonsen, The diatom types of Heinrich Heiden in Heiden \& Kolbe, Bibliotheca Diatomologica 24, J. Cramer, Berlin, Stuttgart, 1992, pp. $1-100$.

[25] A. de Brébisson, Considérations sur les Diatomées et essai d'une classification des genres et des espèces appartenant à cette famille, Brée l'Ainé ImprimeurLibraire, Falaise (1838), pp. 1-22.

[26] A. Grunow, Algen und Diatomaceen aus dem Kaspischen Meere, in: Naturwissenschafte Beiträge zur Kenntniss der Kaukasusländer, auf Grund seiner Sammelbeute, O. Schneider (ed.), Dresden, 1878, pp. 98-132.

[27] E. Reichardt, Eine bemerkenswerte Diatomeenassoziation in einem Queehabitat im Grazer Bergland, Österreich, in: Iconographia Diatomo- logica, 5, H. Lange-Bertalot (ed.), A.R.G. Gantner Verlag K.G., 2004, pp. 419-479.

[28] W. Smith, Synopsis of British Diatomaceae, John van Voorst, London, 1853, pp. 1-89.

[29] A. Grunow, Die Diatomeen von Franz JosefsLand, Denkschr. Math-Naturw. Classe, Kais. Akad. Wissensch, Wien, 48 (1884), pp. 53-112.

[30] A. Grunow, Ueber neue oder ungenügend gekannte Algen, Erste Folge, Diatomeen, Familie Naviculaceen, Verh. Kais-Königl. Zool-Bot. Ges. Wien, 10 (1860), pp. 503-582.

[31] L. Rabenhorst, Flora Europaea Algarum aquae dulcis et submarinae, Sectio I, Algas diatomaceas complectens, cum figuris generum omnium xylographice impressis, Apud Eduardum Kummerum, Lipsiae, 1864, pp. 1-359

\title{
ПРЕГЛЕД НА СЕКЦИЈАТА DISTANTES ОД РОДОТ PINNULARIA (BACILLARIOPHYTA) ВО МАКЕДОНИЈА; ДИВЕРЗИТЕТ И ДИСТРИБУЦИЈА
}

\author{
Александар Павлов, Златко Левков \\ ${ }^{1}$ Институт за биологија, Природно-математички факултет, Универзитет „Св. Кирил и Методиј“, \\ Скопје, Република Македонија
}

\begin{abstract}
Pinnularia е еден од најголемите и најшироко распространети слатководни дијатомејски родови. Сепак, истражувањата посветени на секцијата Distantes од родот Pinnularia се малобројни. Значаен диверзитет на таксони од родот Pinnularia од секцијата Distantes е забележан во водните хабитати на неколку планински области во Македонија. Вкупно се евидентирани 12 таксони, од кои три се опишани како нови видови: Pinnularia idsbensis, P. micevskii и P. subalpina. Главните морфолошки карактеристики се опишани за сите евидентирани таксони. За новите видови вклучени се и оние карактеристики кои ги одделуваат од најсличните таксони. Дополнителен коментар е даден за распространувањето на секој од забележаните таксони како и за хабитатите кои ги населува. Хабитатите кои овие таксони ги населуваат се разликуваат според типот и надморската висина, односно опфатени се: високопланински езера, со глацијално или неглацијално потекло, извори, потоци, реки и тресетишта, како и стари бунари за водоснабдување, а исто така и трајни или привремено влажни карпи.
\end{abstract}

Клучни зборови: дијатомеи; Pinnularia; sectio Distantes; диверзитет; Македонија 